\title{
Hazard identification based on plant functional modelling
}

\section{Rasmussen, B.; Whetton, C.}

Publication date:

1993

Document Version

Publisher's PDF, also known as Version of record

Link back to DTU Orbit

Citation (APA):

Rasmussen, B., \& Whetton, C. (1993). Hazard identification based on plant functional modelling. Risø National Laboratory. Denmark. Forskningscenter Risoe. Risoe-R No. 712(EN)

\section{General rights}

Copyright and moral rights for the publications made accessible in the public portal are retained by the authors and/or other copyright owners and it is a condition of accessing publications that users recognise and abide by the legal requirements associated with these rights.

- Users may download and print one copy of any publication from the public portal for the purpose of private study or research.

- You may not further distribute the material or use it for any profit-making activity or commercial gain

- You may freely distribute the URL identifying the publication in the public portal

If you believe that this document breaches copyright please contact us providing details, and we will remove access to the work immediately and investigate your claim. 
DKa300233

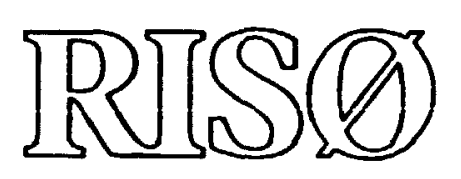

\section{Hazard Identification Based on Plant Functional Modelling}

Birgitte Rasmussen, Cris Whetton

Ris $\emptyset$ National Laboratory, Roskilde, Denmark

October 1993 


\section{Hazard Identification Based on Plant Functional Modelling}

Birgitte Rasmussen, Cris Whetton* 
Abstract A majox objective of the present moxk is to provide means for represenling a process plant as a socin-lechnical system. so as to alkow hazand identifiation at a high level. The method inclukes technical. human and organizational aspects and is intended to be used for plant-level hazard identiluation so as (o) ideniffy critical areas and the need for further analysis using existing methous. The furst part of the method is the preparation of a plant functional molel where a set of plant functions link together hardware. software. Operations. work organisation and other safety related aspects of the plant. The hasic principle of the functional movelling is that any aspect of the plant can be represented by an chject in the sense that this term is used in computer sience) based upon an Intent (or goal); associated with each Intent are Methods, by which the Intent is realized, and Constraints. which limit the Intent. The Methods and Constraints can themselves be treated as objects and decomposed into lower-level Intents (hence the procedure is known as functional decomposition) so giving rise to a hierarchical. whject-oriented stnucture. The plant level hazard identifcation is carricd out on the plant funclional model using the Concep Hazard Analysis method. In this. users will be supported by checklists and keywords and the analysis is structured by pre-defined worksheets. The preparation of the plant functional model and the performance of the hazard identification can be carried ouk manually or with computer suppor.

The present repont is the main deliverable of work package 3.1 of the project An Overall Knowledge-based Methodology for Ha:ard Identification sponsoxed by the CEC STEP programme (contract mo. STEP-CT90-0085).

Window's is a registered trademark of Microsoft Corporation.

ISBN 87-550-1933-I

ISSN 0106-2840

Grafisk Service. Risø, 1993 


\section{Contents}

1 Introduction 5

2 Overall description of TOMHID 7

2.1 Overall TOMHDD procedure 7

2.2 Orecome of the TOMHID procedure 8

3 Prieciples of fosctioned modeling 9

3.1 Scope of the functional model 9

3.2 Functional modelling 9

3.2.1 Overall modelling principles 9

3.2.2 Functional description 10

3.2.3 How to start - where to stop II

3.3 Presentation forms 12

3.3.1 Tabular form 12

3.3.2 Graphical form $/ 3$

3.4 Plant functional objects 14

3.4.1 Establish the Intents of the plant 14

3.4.2 Establish the Methods and Constraints of the plant IS

3.4.3 Systems and items with multiple functions 16

3.4.4 Dynamic aspects of processes 17

3.5 Operations and management issues 17

3.5.1 Operations issues 17

3.5.2 Management issues 18

3.6 Procedure for functional decomposition of a process plant 19

4 Principles of CHA applied with functional modelling 20

4.1 CHA on a plant functional model 20

4.1.1 Agree on a set of CHA keywords 20

4.1.2 Partition the plant into sections $2 I$

4.2 Performing the CHA 22

4.2.1 CHA without computer support 24

4.2.2 CHA with computer support and with the plant functional model 25

4.3 Supporting databases 25

4.4 Supporting analyses 26

4.4.1 Concept Socio-lechnical System Review (CSSR) 26

4.4.2 Preliminary Consequence Analysis (PCA) 27

4.4.3 Short-Cut Risk Assessment Method (SCRAM) 27

5 Conclusions 29

5.1 Arising from the batch case study 29

5.2 Arising from the continuous case study 29

5.3 General 30

Acknowledgements 32

References 32 
A Case stody of a bact reactor phat 33

A.1 Ineroduction 33

A.2 Shon description of the batch reactor pland 33

Information about the involved chemical substances and their combustion products 3 ;

Quantities of chemical substances involved in the different activities if Information about processes and chemical rexctions 34

The overall structure of the PMP plant 35

Information relating to the organisation and the management is

Quality assurance system 36

Emergency plan for bazardous releases and large fires at KVK 37

A.3 PMP plane functional model 37

A.4 Concept Hazand Analysis 37

A.5 Results 38

Identified potential hazards 38

Identified sources of hazards and the cunditions under which an axcident could occur 38

Assessment of accident consequences 38

Safety measures 38

B Case study of a section of a continuous process plant 53

B.1 Introduction 53

B.2 A brief plant section description 53

B.3 Plant section functional model 53

B.4 Hazard analysis of the functional model 54 


\section{Introduction}

An importan par of a safety analysis of a cherical process pland is the ideatifrcation of hazand and this can be carried on at eidter wit or plan kevel. Methods exist for harard identification at unit kevel. e.z. hamed and operability sady (HAZOP) and faibre mode and effect andysis (FMEA). For brge chemical process planes the eflont required by these methods can be very exlensive and it can be very difficul to establish a wal rist survey for the pland. Furthermore, the emphasis of these methods is on identification of hands closely reloned to the vechnical aspects of the pland and less on barnds related to the interaction between the plane equipment the organisational structure and the mangeweal fac tors.

The present report is pert of the project entilied "An Overall Knowledge-besed Methodology for Haned ldentification" which is sponsored by the CEC STEP research progromme. The working tite of the project is: TOMHD. It was initined in 1991 for a duration of three yers. The project is caried on by an inernetional consortivem incheding the following parmers: VTT (Technical Research Cenere of Finland). The University of Shefiredd (United Kingdom), SRD Division of AEA Consulking (United Kingdom), Tecsa (ltaly), CIEMAT (Spain), Joint Reserch Centre (Ispra) and Ris National Laborreory (Denonat).

The basic idea of the TOMHID project is to develop an overall methodology which will provide assistance and guidance to the user for hazard identification purposes and which follows the course of an incidend in each stage of the event chain.

One of the major objectives of the project is to provide a comprehensive framework to represen a process plant as a socio-technical system. The methodology is to include lechnical, human and organisational aspects and is intended to be used as a first stage in the hazard identification process so as to identify critical areas and the need for further analysis using existing methods.

The TOMHID project consists of the following work packages:

- WPI: Review of existing methods and models used for hazard identification.

- WP2: Conceptual study of hazard identification and risk reducing methods.

- WP3.1: Link between the functional model and hazard identification.

- WP3.2: Development of method to investigate management factors related to causes and consequences of specific hazards.

- WP4: Specification of software.

- WPS: Implementation of software.

The object of the TOMHID project is a method which can provide assistance and guidance to the user for high level hazard identification of different kind of chemical process plants (batch reactor plants, continuous plants, mixed reactor plants). The final method will consist of the following main elements:

- a functional description of the plant as a socio-lechnical system

- high level hazard identification based on the Concepe Hazard Analysis method (CHA)

- plant documentation comprising the functional plant model and the plant level hazard identification

- evaluation of the safety impact of management factors on the identified hazards (to be developed in work package 3.2 of the TOMHID project) 
- surtware specifiaction and implemenation of the methuls develuped in aurt patage 3.1 (w) be developed in wort patages 4 and 5 of the TOMHD pniject).

The present report has heen prepared by The University of Sheffrebl and Riso Nainmal Laburatury and is the main deliverable of wurx pactage 3.1. Chapper 3 con-

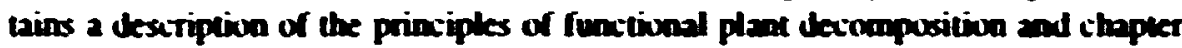
4 presents the primiples for high level hazand identifizativa based on the Concept Hazard Analysis method (CHA) applied wo the fonctional pland maxkl. In the appendices two examples (a bath rezilur plant and a comtinuves process pland) are presented illustrating the principles of functional plant decomposition and Concept Hazard Analysis.

The present wort is based on the following working chcuments resulting frum the first two work pactages of the TOMHID project:

- Users Need Report. Fetruary 1992. 18 pp + appendices (WPI).

- Review on Hazard Identification Methods and Software Tools. April 1992. 122 Pp (WPI)

- Coxceptual Study of Hazand Idemifization and Ristk Redecing Methods. Manch 1993. $104 \mathrm{pp}+$ appendices (WP2). 


\section{Overall description of TOMHID}

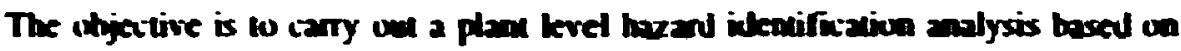
the plane funtivanal mulet using Cumcept Hazard Amalysis (CHA) in a sorectured

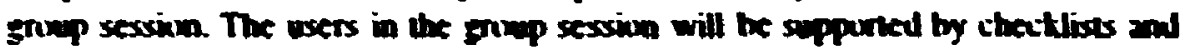
keywinds guiding and struituriug the andysis. The malysis will idenify critical areas and the need for further analysis where wellesablished apprenches can be applied.

\subsection{Overall TOMHID procedure}

The overall TOMHID procedure is:

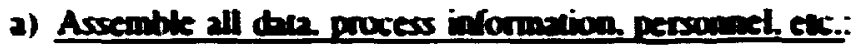

Data requirements and composition of the vean are similor to those of an ordinary HAZOP. (Klet. 1992).

b) Define the seupe and chiectives of the stady:

The objectives will generally be thase of TOMHD. identifcation of pland hazands and areas requiring more detailed study. Scope will usually be that of the entire pland. its management. and envirunment. However. all requiremenes may he changed to reflect the needs of the stody.

c) Rezister Informzation:

This consists of howsekeeping activities such as the project name. name of the analyst. and reference documents; it is descrithed in detail (Davies \& Whetton. 1993). The most significan procedural decision mate bere is whethet the analysis is to be manual or automated, as this dictates bow some of the later software is configured and linked logether.

\section{d) Compile Sulustance List:}

This involves compiling a list of those substances present in the system. their quantities, and their locations in terms of vessels, pipes etc. This is described in detail (Anon., section 4, 1993) and (Davies \& Whetion. 1993). Regardiess of the selected mode. the Suhstance List will always the available for consultation by the user. This data should be available from process engineering. who would be requested to supply it. and will the used to guide the analyad as to substance properties at each point in the model.

e) Make Functional Model:

The functional model is required in the automated version of TOMHID but is opional in manual mode. A consequence of this is that, in auln mode the model and the forms used for CHA are linked together so that movement through the CHA form is controlled hy movement through the model whereas in manual mode the (wn forms are independent. Construction of the model is described in detail in chapter 2 of this repont. while the software functions are detailed in (Davies \& Whelton, 1993).

1) Concepl Hazard Analysis:

Description of the CHA procedure is presented in chapher 4: however. reference is made in the original description (Anon., section 4. 1993) and in the softwase description (Davies \& Whetion. 1993). 
s) Other TOMHID Amalyes:

The veler andyses are supplemenary w CHA and are described in the references as:

- Concep Sociviectaical System Review (CSSR) (Ama . sectivan 4. 1993).

- Pretionianary Consey ence Amolysis (FCA) (Avon. section 4.3. 1993).

- Shon-Cur Rist Assessencen (SCRAM) (Anon. Section 4.4. 1993)

h) Mure Detriked Andres:

Odher andysis methods may be esed wo explure particular hararis identified by TOMHID (Anum. section 5. 1993).

\subsection{Outcome of the TOMHID procedure}

The overal onecome of the TOMHID procedure will be a docamede contiaing fow elemenes:

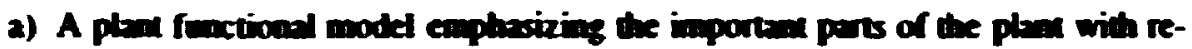
spect to salety. The model will be developed on the basis of the phent docamentation and on the prisciples of fenctional decomposition.

b) A documened Concept Hazred Analysis comprising analyses and evaluation of the objects contained in the plas model.

c) An idencifization of the plane units (or parts of plant unies) that are critical from a sarety point of view. Recommentations concerning further analysis where well-established hazard identification and failure analysis methods can the applied.

d) Suggestion of measures which can reduce the possibilities of limit the consequences of the identified havands. 


\section{Principles of functional modelling}

\subsection{Scope of the functional moded}

The seupe of the fonctional molel is:

- un provide a generd franewut for representing a chamical process piba as a suxinstectuiatal system

- us seppert be Concep Hand Analysis which will be the statiog poin for the sobseguent evalation of the salety impact of the mangemean factors on the ilentified haxants.

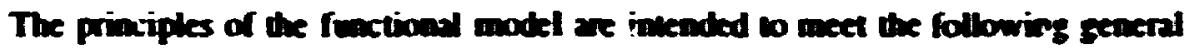
requireanesins:

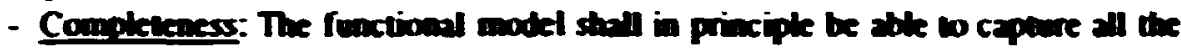
safety relaed information and apects of the socio-bectuical sysuem (e.s. equip-

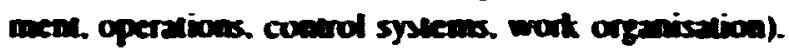

- Fexibility: It stall be pasible to perform the fenctionol modelliag and decom-

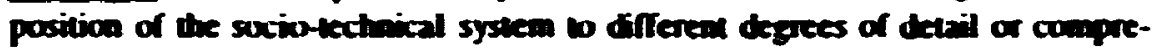
hesciveness. The eser most be able to decide where the enplessis of the andysis shall be laid.

- Rohwoness: During factional modelling of the pland the wer sholl be able to exlend the scope or the modelling level of detail withont brealing the incemal consistency of the plan model. This meas thet the fenctional model can he dereloped incrementally.

In this chapter the hasic priaxiples for fonctional modelling and cecomposition are presented and in illustrate these principles iwn exangles of functional modelling have been prepared and can be froud in the appendices.

\subsection{Functional modelling}

The overall goal of the fonctional modelling and decomposition is in prepare a systematic and comprehensive description of a poncess plan with reference in hazard identification. The inention is to represent a socio-echnical system as a hieranchical, shject-oriented stucture.

\subsubsection{Overall modetions prixciples}

The plant model follows a general framework as indicated in Figure 1. The basic idea is that a set of plant functions link together hardware, sofiware. operations. work organisation and other safety related aspects of the plank. Within this framewotk it will be possibte to integrate information and knowledge ahout the techaical. physical and functional configuration of the pland logether with relations and connections in the operalions and its management aspects. The basic principle of functional modelling is that any aspect of the plane can he represented by an ohject hased upon an Intent or goal and that assoxiated with each Intent are Methnds, hy which the Intent is realized. and Constraints, which limit the Intent. The Methous and Constraints can themselves be treated as objects and decomposed into lower-level lintents (hence the procedure is known as funclional decompnxi(ion). sn giving rise in the method's hierarchical structure. 
Develupanent of the hierantical structure proceeds as follows: A staning poim is chosen (bere defined as FO). Usaally this will be the up kevel of the phen - its owerall fonctiva - bat can be the fonction of a pland section if so desired $A$ the

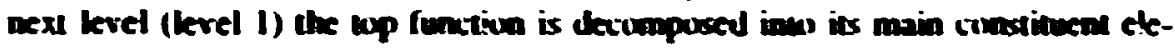
menes. say FI. F2. F. The factivand decumpuxition is contioned and refiand at

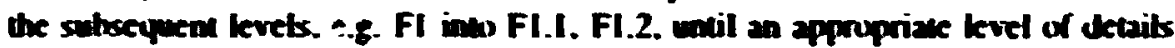
has been achieved This principle is illestraned in Figuse $I$.

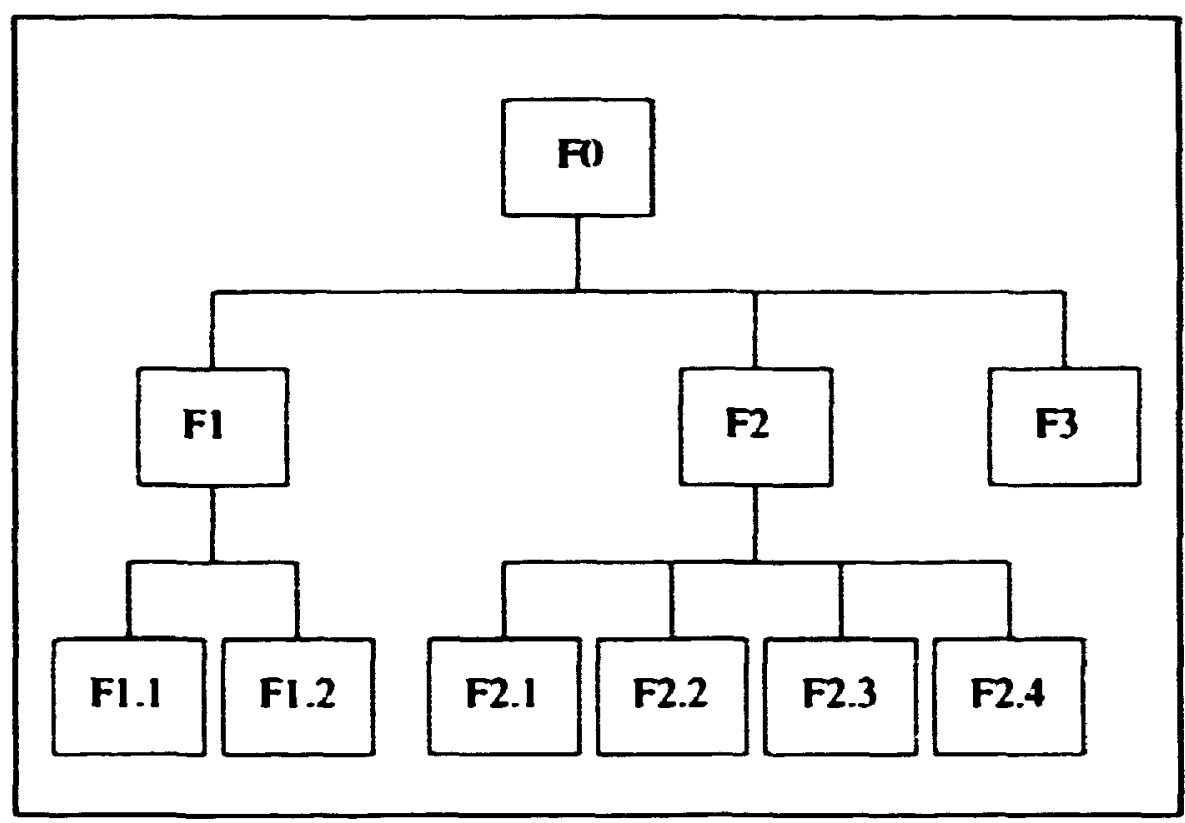

Figure I. Funcrional dernmponsition of a provess plant as a hierarchy of funcrional objeress.

\subsection{Frenctional description}

In the plane functional model. a function is an ohject comprising an Inem, a lise of mone than one Methods, which are used to satisfy that Inend. and a list of zero or unore Constrainks. which impose restrictions upon the Inemu. Each element of the lists of Methots and Constraints can itself the treated as an ohject defining a new Intent with its associated Methods and Cowstrainks. A simple semantic model is shown in Figure 2.

\section{<Intents by <Methodss with <Constraints>}

Figure 2. Semantic funcrional model.

Hence. the plant model contains nhjects whose elements can he classified as follows:

- Intents representing the functional gonals of the specific plant activities in quexiim.

- Methods representing items (hardware, procedures, softwarc. cle.) that are used in carry nut the Intent or operations that are carried oul using thrse items. 


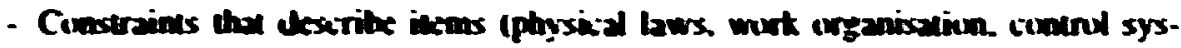

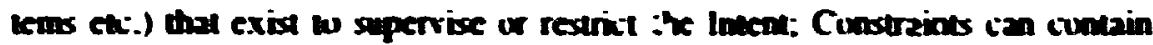

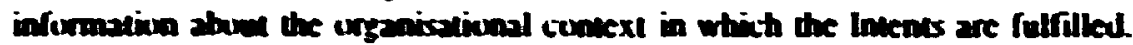

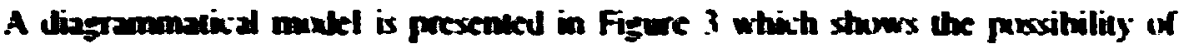

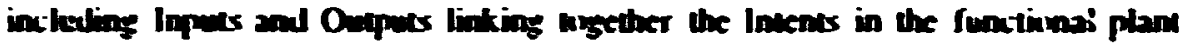
mudet. Ingets show the accessory contitions ks perform the Ineent and the link to

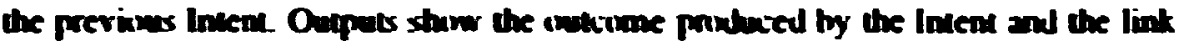

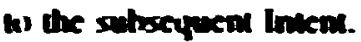

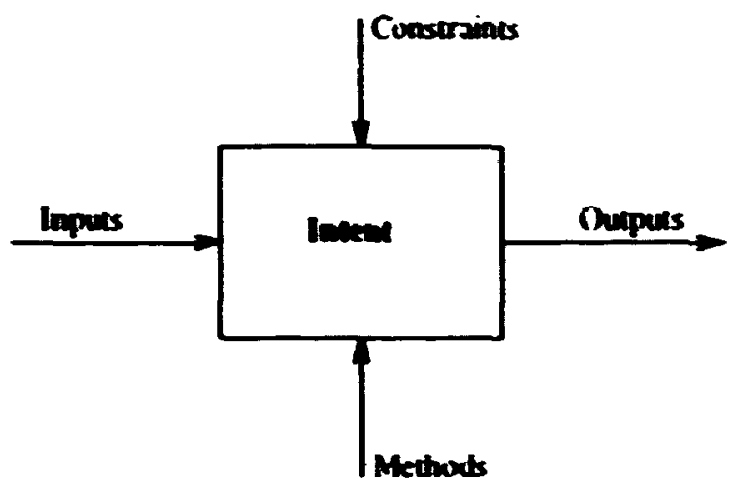

Figure 3. Intertelationships berwern nbjerts at the some funrtional Irvel.

Finally. in some cases in may be convenient to divide the fonctional pland movel

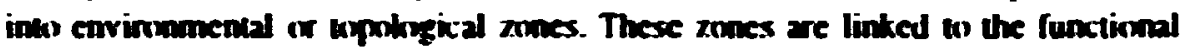
ohjects and specify where an Intent is carried ow and they give information abowt the hacal situation.

\section{$3.2 .3 \mathrm{hlow}$ to slart - whe to stop}

The modelling principle is a top-down appoach which ensures a lngic functional model of the process plan. One of the exsential parts of the functional decompositim is to determine the starting point of the analysis. To state a general starting pmind which will he convenient for all kind of hazard identification analyses is mo possihke. as an appmpriate starting point will depend on the specific plant configuration and the nhjective of the analysis. The usual starting pinit will he a process Inowsheet for the plant and from this the analysa will have information on all the chemical suhstances and the characteristics of the main process streams. From this stanting prind. the functional decompasition is perfommed. ensuring that all relevan activities are considered (processing. maintenance. comimls. emergency systems etc.).

The structural decomprsition of a process plant may follow the following hicrarchy:

1. plant (or section of the plant)

2. unit

3. system

4. suhnyslem

5. aggregaic

6. comprnont

7. piece part 
(Note, however, that the analyst may insert intermediate functions which do not correspond to the physical elements if by so doing the clarity of the analysis is enhanced).

For a particular plant, there will be one plant object, one or more unit objects, and as many objects of the lower levels as there are systems, subsystems etc. in the plant. As for the starting point, it is not possible to offer general rules for selection of an appropriate modelling level. The intention is to identify at each level those parts of the plant where further analysis is required; meaning that the degree of detail will differ for the different parts of the plant. Here it is impontant to keep in mind that the main purpose of the functional model is to provide a frame for a high level hazard identification; consequently the model may be stopped at one of the top levels. Furthermore, it must be remembered that one of the objectives of the high level hazard identification is to identify critical areas and the need for further analysis. At some other stage existing hazard identification and failure analysis methods e.g. Hazard and Operability Studies, Failure Mode and Effects Analysis, Action Error Analysis, will be more suitable for the detailed analysis work.

\subsection{Presentation forms}

The main objective of the plant functional model is to provide a frame for the overall hazard identification. In the following it is assumed that a Concept Hazard Analysis will be carried out using the worksheets (or variants hereof) presented in chapter 4.

The plant functional model can be developed and presented in two different ways: tabular or graphical form. These two presentation forms can be used separately or they can supplement each other. For each plant or activity the analyst can choose the most convenient way to develop the functional decomposition and present the plant model. Applications of the tabular form and examples of the graphical presentation form can be found in the appendices. However, it must be noted that, with regard to the software specification developed under WP4, the graphical method has not been developed, except so far as it is used in abbreviated form to allow the user to navigate through the model, as described in section 4.2.2 of this document.

\subsubsection{Tabular form}

Choosing a tabular presentation form will make it easier to develop a frame for the overall hazard identification as the worksheet from the functional model can easily be linked to the worksheet of the Concept Hazard Analysis.

The functional model can be contained in a three column worksheet as shown in Figure 4 where the "Ref" column is used for numerical reference as explained later. The "T" column is used to indicate the type of the object by the letters I for Intent, $\mathrm{M}$ for Method and $\mathrm{C}$ for Constraint. The "description" column contains an imperative statement which forms the Intent, Mcthod or Constraint. 


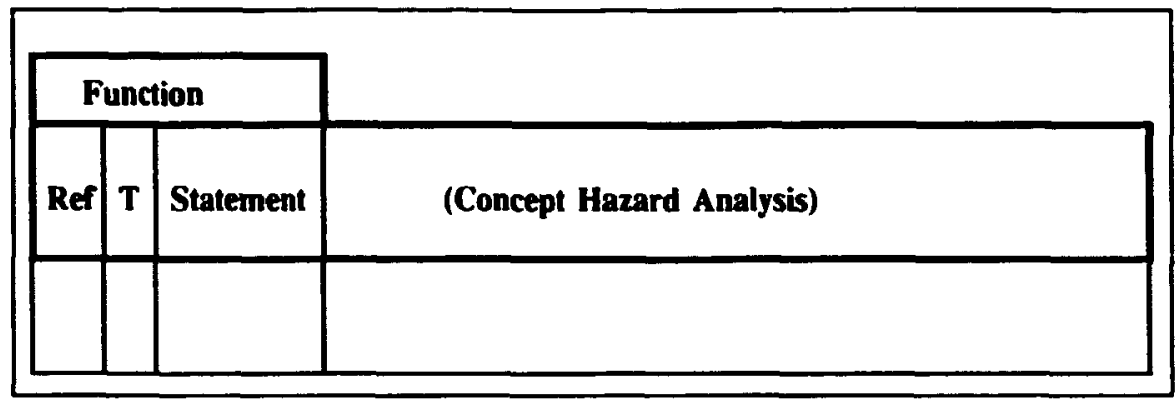

Figure 4. Tabular presentation form.

To make the functional model more readable a column for comments or notes can be included in the worksheet. The comments or notes are for explanation only and do not form part of the plant functional model.

As indicated a reference (numbering) system is used to clarify the functional decomposition. A decimal numbering system is proposed, as follows:

- the first Intent of the model is reference 0

- the first list of Methods is numbered sequentially $1 . . . n$

- the numbering of the first list of Constraints starts at $n+1$.

If a Method or Constraint is expanded, then it generates a new Intent which is numbered i. 0 which has a new list of Methods numbered from i.1 to i.n and a new list of Constraints starting at i.n+1. This presentation form is unambiguous but can result in lengthy reference numbers (a problem which seems to be unavoidable).

Finally, it is recommended that, in order to keep the clarity of the plant functional model, the numbering of Methods and Constraints follow as much as possible the logical sequential order with respect to the processes and activities at the plant. One way to illustrate the Input/Output relations between the plant objects in the tabular plant functional model is to list the Methods in the same sequential order in which they are performed to fulfil the requirements of the Intent in question. (Note, that activities in parallel can be indicated either by use of a logical OR or by the imposition of a suitable Constraint).

\subsubsection{Graphical form}

In several cases a graphical presentation form can be useful as a supplement to the tabular documentation. In the graphical presentation form the functional objects of the model follow the general format as illustrated in Figure 3 and which follows the usual conventions of the SADT (Structured Analysis \& Design Techniques) method of systems analysis.

The main benefit of using the graphical presentation form is that it is possible in a clear manner to show the main streams and the internal functional relations of the plant. For activities where for instance failure propagation is considered to be an essential safety aspect the preparation of a graphical presentation of the functional decomposition might help to identify the incident course and the critical plani areas.

If a graphical presentation form is chosen the outcome of the functional plant decomposition will differ from the outcome based on the tabular presentation form. 
In general the same objects can be found in the two presentation forms but a different structure of the functional model will often be convenient. The graphical form has the advantage that it will almost always be possible in one diagram to contain more than one Intent together with the respective Methods and Constraints.

A disadvantage with the graphical presentation is that the development of the functional diagrams can be rather time consuming and they can be more troublesome to update and correct. A good software editor will reduce this problem. Furthermore, to carry out the hazard identification it is necessary to transfer the objects of the diagram onto a tabular form to which the CHA worksheet can be connected. For these reasons, it is proposed that the computerised version of TOMHID will incorporate a graphical representation that shows only the model structure, content being given in the tabular displays.

\subsection{Plant functional objects}

The technical configuration of chemical process plants clearly differs from plant to plant making it rather difficult to formulate explicit rules for carrying out functional decomposition. It must be stressed, that the decomposition of a plant or unit into its functional elements is not a well-defined exercise with only one outcome it can be done in different ways depending on the experience and choices of the analyst.

On the other hand, examples and guidelines may be useful and it is to some extent possible to exemplify the kind of information that is intended to be represented at the different functional levels. Examples of functional objects can be found in the following sections. Furthermore, some problems which may arise during a functional decomposition of a process plant are discussed. Detailed examples and application of the principles of functional decomposition can be found in the appendices.

It must be stressed that the basic idea is to develop a procedure which can structure and support plant level hazard identification by use of the functional decomposition principles. It has not been the intention to develop a real taxonomy for representation of functional objects in a plant model.

\subsubsection{Establish the Intents of the plant}

One question is how the different functional objects are to be characterised. If, as an example, we consider a chemical batch reactor equipped with a temperature alarm, the question is whether the temperature alarm should be characterised as a Method (equipment used to realize the Intent) or as a Constraint (equipment used to control the Intent). Since the reason for making the plant functional model is eventually to perform a plant level hazard identification, the important point is not how the object is characterised, but that all objects important to safety appear in the functional model of the plant. The basic principle of the functional modelling in which any aspect of the plant can be represented as Intent by Methods with Constraints is a valuable way of thinking to ensure that all safety aspects have been considered. It cannot be over-emphasised that it is more important to ensure that all those objects which affect safety are included, than to be concerned as to whether or not they are included exactly in the right place. In each case it must be considered whether the choice of function and the way in which it is expressed 
will influence the performance and result of the subsequent plant level hazard identification.

Determining the Intent of a plant and distinguishing the Intent from Constraints (and sometimes Methods) is a matter of some judgement as the following examples show:

Intent: Make liquid oxygen. This is clearly an Intent and nothing but.

Intent: Make liquid oxycen by liquefaction of air. Here, the Intent has been mixed with the Method "by liquefaction of air".

Intent: Make liquid oxygen at a cost lower than floltonne. Here the Intent has been mixed up with the cost Constraint.

Intent: Make liquid oxygen with noble gasses as a by-product. This is a valid Intent which can be split into two subsidiary Methods "Make liquid oxygen" and "Extract noble gases as by-products".

The best way to decide whether an Intent is correct is to examine each clause of the sentence and see if it is a Method or a Constraint. If is either, then the clause is removed from the Intent statement and replaced in the category it belongs. As a general principle, the top Intent should be kept as simple as possible, while still crpturing the essence of the plant.

Another aspect related to the determination of plant Intents is the identification of those production units and activities which will be the principal parts of the plant functional model. The logical starting point for the functional decomposition will often be the specific Intent of the plant. Here it is important to keep in mind that this choice will often lead to a fragmented structure for auxiliary operations highly integrated in several Intents e.g. the control system, maintenance operations, quality assurance system, procedures for handling chemicals, emergency system. These auxiliary systems will appear at those points in the functional model where they are considered to be important from a safety point of view, while the structure of the entire systems may not appear clearly any where. If the tasks of the auxiliary systems are separated and only included in the functional model where relevant it must be considered how to ensure a complete analysis covering all relevant tasks of the auxiliary systems. Consequently, there may be occasions when it is desirably to decompose the system starting from the auxiliary system Intent. E.g. the safety of maintenance operations could be examined by starting from Maintain the plant as the top Intent.

\subsubsection{Establish the Methods and Constraints of the plant}

"Methods" and "Constraints" are objects related to a specific Intent at a specific plant level. "Constraints" comprise activities, installation or systems that restrict or control the Intent. Generally speaking "Constraints" can be equipment, supervision and/or management. "Methods" comprise hardware (i.e. equipment and chemicals) used and procedures or operations carried out to realize the Intent.

Having established a valid Intent for the plant the next step/task is to decide the Methods available to implement the Intent and the conditions which restrict the Intent. It is impossible to prepare a complete list of Methods and Constraints relevant to the plant functional model, but Tables I and 2 contain some high level standard Methods and Constraints, respectively, which it is recommended always to consider during the development of the plant functional model. 
Table 1. Standard Methods.

\begin{tabular}{|l|l|}
\hline Mothod & Suggestions for expending the Lethod \\
\hline Manage the operation & $\begin{array}{l}\text { Feedstock loading; Intermediates; Plant cocrdination; Pro- } \\
\text { duction activities; Product unloading; Safety cuture. }\end{array}$ \\
\hline Support the operation & $\begin{array}{l}\text { Catalyst loading: Cleaning: Construction; Control process; } \\
\text { Deployment; Firefighting; Loading; Maintenance; Manage } \\
\text { emprgencies; Modfication; Painting; Ouality control: Security: } \\
\text { Shutdown; Stan-up; Storage; Testing: Training: Transport; } \\
\text { Unloading: Waste disposal. }\end{array}$ \\
\hline
\end{tabular}

Table 2. Standard Constraints.

\begin{tabular}{|l|l|}
\hline Constraint & Suggestions for decomposition of the Constraint \\
\hline $\begin{array}{l}\text { Protect environment } \\
\text { trom damage by plant }\end{array}$ & $\begin{array}{l}\text { Avoid accidental releases } \\
\text { Contain process fluids } \\
\text { Control effuent disposad } \\
\text { Minimize acoustic emissions } \\
\text { Minimize planned releases }\end{array}$ \\
\hline $\begin{array}{l}\text { Protect plant trom } \\
\text { damage by environment }\end{array}$ & $\begin{array}{l}\text { Protect against incidents in adjacent plant } \\
\text { Protect against man-made disasters } \\
\text { Protect against natural disasters } \\
\text { Protect against unauthorized access to plant }\end{array}$ \\
\hline
\end{tabular}

The first standard Method "manage the operation" presented in Table 1 refers to production activities while the second "support the operation" covers everything else. Supporting tasks are often not covered sufficiently in hazard analyses. Including these Methods at a high level ensures an appropriate integration of these aspects in the analysis. Supporting tasks should be examined at each stage of the functicnal decomposition to see whether a particular Method is appropriate for inclusion.

Currently, two standard Constraints have been identified for inclusion at level $\mathbf{0}$ in the plant functional model (Table 2): "Protect environment from damage by plant" and "Protect plant from damage by environment". These are clearly complementary and it should be noted that personnel are included in the concept of Environment. The lists of Table 2 suggest some Methods into which these Constraints can be decomposed.

\subsubsection{Systems and items with multiple functions}

It can sometimes be difficult to decide where an object belongs, as the following two small examples show:

- Heat exchanger: is the primary purpose to heat stream A or cool stream B ?

- Pump: is the primary purpose to empty tank A or fill tank B ?

These examples are trivial, but they do illustrate an important point: where a hardware item has multiple functions, these functions may appear separately in the appropriate parts of the model. The modelling problem is bipartile:

- A multiple function will appear frequently. Indicating all relations to and impact on other functions can easily diminish the clarity of a functional model. 
- If the tasks of a multiple function are separated and only included in the functional model where relevant it must be considered how to ensure a complete analysis covering all relevant tasks of the multiple functions.

In general this presents no great problem; however, if a clearer relationship between function and equipment/hardware hierarchy is required then means must be found to accomplish this.

\subsubsection{Dymamic aspects of processes}

The principtes for decomposition of the plant functional model have been developed for application to batch processes as well as continuous processes. In some cases the dynamics of the system can be a critical safety factor; e.g. an important dynamic factor for batch processes can be time and for continuous processes flow.

In general it is important to assess the impact on plant safety of the dynamic behaviour of a system. Relevant dynamic factors can e.g. be: time, flow, temperature.

\subsection{Operations and management issues}

\subsubsection{Operations issues}

"Methods" and "Constraints" identified as operations can be difficult to decompose in a clear and logical manner. In Table 3 a general list of operations is presented which can support the functional decomposition. The idea is to write down a broad sample of actions that may appear at a process plant. In the content of functional modelling, the intention is that operations arp related to a specific Intent where it is considered important from a safety point of view.

Observation and manipulation cover the physical interaction with plant and equipment, while evaluation is a mental task. Communication includes telephone calls, reading production schedules etc. Control is reserved for terms that refer to higher level manipulation or special control concepts such as set points. The three first categories may be seen to form an observe - evaluate - manipulate loop, modelling the central operator actions, with the next two categories serving as tool families. Plants with high degrees of automation have a central control system operating the whole plant with the operator merely monitoring the needs of the control system. Plant maintenance, which is an important but often overlooked aspect of system safety, also involves the functions of observe, evaluate etc. and is also included as one of the standard Methods of Table 1.

Table 3 attempls to present the tasks of an "operator" according to the basic verbal meanings and the lists are not reduced to minimum sets representing the necessary operator tasks. The list is presented here as a rough sketch of possible input parameters to error lists and to suggest a background for wording the functional model at the lower plant levels. 
Table 3. A general list of operator actions.

\begin{tabular}{|c|c|}
\hline observe & $\begin{array}{l}\text { read (instrument, bow, sign scheme, text); listen; } \\
\text { feel (temperature, movement); smell; measure } \\
\text { (weight, coumt); check; inspect; lock atter; measure if }\end{array}$ \\
\hline evaluate & $\begin{array}{l}\text { compare (with reference, target value, scale, plan): } \\
\text { review (observation, data, experience); judge; } \\
\text { decide; choose plan, strategy or procedure }\end{array}$ \\
\hline $\begin{array}{l}\text { manipulate objects (goods, } \\
\text { bodies, substance) }\end{array}$ & $\begin{array}{l}\text { take; carry; return; load/unload object; filvempty } \\
\text { container; add/remove; add substance; treat sub- } \\
\text { stance; move; tithower; turn; position; secure; } \\
\text { lockloosen }\end{array}$ \\
\hline manipulate equipment & $\begin{array}{l}\text { establish; connect/disconnect; assemble/dissemble; } \\
\text { install; adjust; reset; activate; deactivate; open/close; } \\
\text { select; fillempty; clean }\end{array}$ \\
\hline $\begin{array}{l}\text { manipulate tools and } \\
\text { instruments }\end{array}$ & $\begin{array}{l}\text { press; push; turn; draw; modify/work on; vibrate; } \\
\text { measure; connectdisconnect remove; exchange; } \\
\text { reset }\end{array}$ \\
\hline communicate & ask; answer; inform; contact; record; log; write \\
\hline control & $\begin{array}{l}\text { initialize; prepare; observe state; check state; } \\
\text { change state; increase attention; reset; steer }\end{array}$ \\
\hline
\end{tabular}

\subsubsection{Management issues}

As mentioned. one of the main objectives of the functional model is to represent a process plant as a socio-technical system. One of the important elements in this connection is representation and integration of management issues and work organisation in the functional plant model.

In this part of the project the analysis of management factors is limited to an identification and integration in the plant model of the management factors. In work package 3.2 methods to investigate the impact of management factors on plant safety will be further developed.

Management issues will usually be developed from standard Methods (Table 1) or standard Constraints (Table 2). If this approach is followed, then the functional sub-model of the management issues may not correspond to that of the rest of the plant - especially to that of its physical sub-structure. Within the functional model, there is no requirement for the structure of one sub-model to correspond with that of another. However, the lack of structural correspondence may cause confusion. One solution to this problem is to integrate management issues into the model by means of a bottom-up approach. In this case, the starting point for functional decomposition is the low-level function and the management issues are only integrated into the functional model if they are considered to be important from the point of view of safety. Table 4 contains some examples of management issues which can support the functional model. 
Table 4. Exanples of management issues.

\begin{tabular}{|c|c|}
\hline system climate & $\begin{array}{l}\text { technical adsorption; legistation: regulations; political climate: } \\
\text { economic climete; business tactors; puttic retetions }\end{array}$ \\
\hline organisation structure & $\begin{array}{l}\text { corporate mission and philosophy; resource provision: deci- } \\
\text { sion-making hierarchy: satety policy: corporate culure: inter- } \\
\text { action with other sociotectuical system }\end{array}$ \\
\hline management structure & $\begin{array}{l}\text { resource allocation; level of stalting; competence; quality } \\
\text { control; commend structure; activity monitoring; setting and } \\
\text { maintaining standards; supenvision; third paries relations } \\
\text { (contractors); response to chenge; salety responsibitities; } \\
\text { accidentincident investigation }\end{array}$ \\
\hline information & $\begin{array}{l}\text { data processing; aveibability; intertaces; cperating proce- } \\
\text { dure/manual; task specification; quality assurance manual; } \\
\text { emergency procedures }\end{array}$ \\
\hline communication & $\begin{array}{l}\text { channels; emphasis; imterface/exchange media; incident } \\
\text { reporting; emergency back-up }\end{array}$ \\
\hline
\end{tabular}

\subsection{Procedure for functional decomposition of a process plant}

The functional model approach proposed has the advantage that it offers the possibility of representing all facets of the plant description (activities, hardware, operations, work organisation) in an integrated and consistent way. The procedure proposed to carry out the functional decomposition of the plant is the following:

a) Discuss the overall goal of the functional model.

b) For large complex plants it might be necessary to perform the functional modelling of the plant activities by subdividing the plant into systems, subsystems etc. and perform a functional decomposition for each part.

c) Determine the principal parts of the plant and the starting point for the functional model.

d) Choose the documentation form for the functional model and the hazard identification. If performing a manual decomposition, then choose a format such as that shown in Figure 4 or the graphical form discussed in section 3.3.2. Otherwise, the computer-assisted TOMHID tool can be used, as described in section 4.2.

e) Establish the top Intent of the plant.

f) Link the Intent with the Methods that are used in carrying out the Intent.

g) Identify Constraints and link them to the Intent.

h) List the Methods and Constraints; if possible, in a logical sequential order with respect to plant design and the operations carried out.

i) Discuss the identified Methods and Constraints and identify those which are going to be further decomposed.

j) Prepare the new list of Intents and proceed from point d.

k) The functional decomposition is finalized when an appropriate level of detail has been achieved. 


\section{Principles of CHA applied with functional modelling}

The previous section described how a process plant may be modelled by the functional method; this section describes how a Concept Hazard Analysis (CHA) may be performed on that model.

\subsection{CHA on a plant functional model}

A general method for CHA is described in (Anon, section 4, 1993), primarily in connection with the manual version of TOMHID and without reference to the functional model. Figure 5 shows the CIIA procedure which is identical for automated and manual modes, the only difference being the linkage between the analysis form. and the functional model, as described in section 2.1.

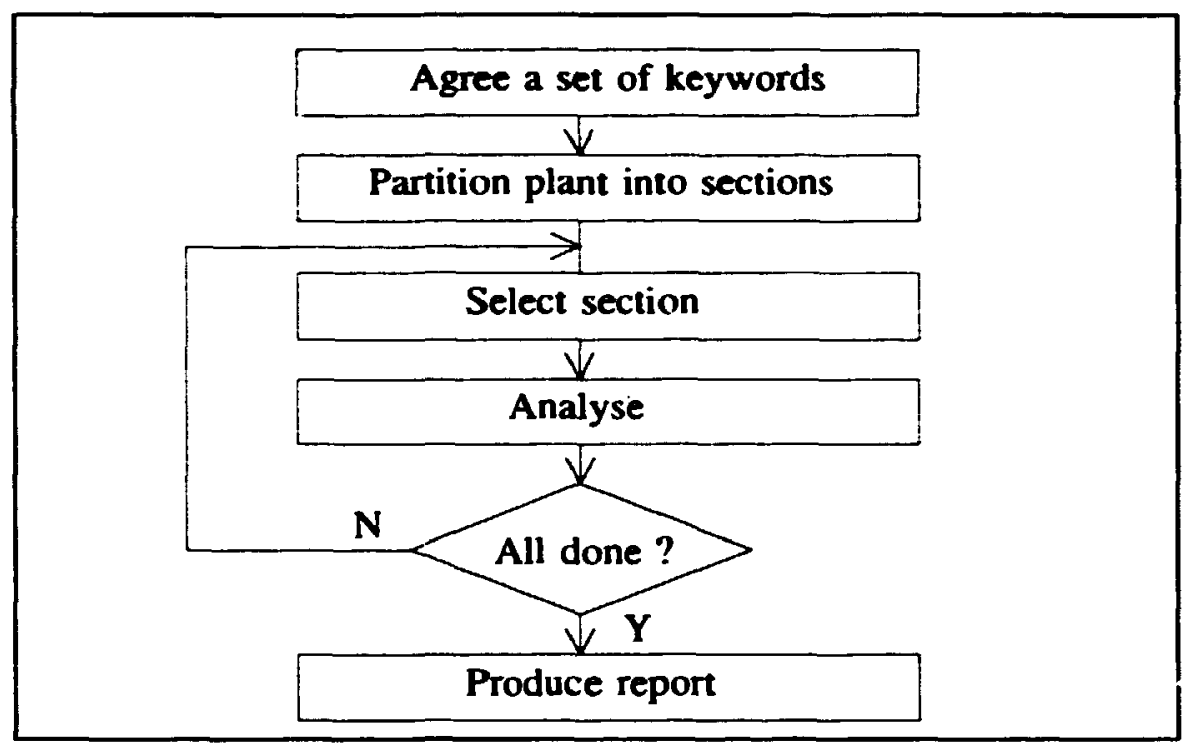

Figure 5. Overall CHA procedure.

\subsubsection{Agree on a set oi CHA keywords}

A Task-specific CHA Keyword Database (CKD) must be assembled for each analysis, in accordance with the procedure shown in Figure 6.

A programme module Edit CKD is used to add (and, deliberately with some difficulty, to delete) keywords to a file known as the Core CKD. This file will contain keywords which are applicable to a variety of industries and situations and from these a database, Task CKD, must be assembled, using ti. Abstract tool, containing only keywords applicable to the analysis (examples of keywords can be found in the appendices and in (Wells, Wardman \& Whetton, 1993)). The details of this database (location, filename, etc.) are added to the registration data. Typically, ten to twenty keywords will be abstracted from the Core CKD to the Task CKD. Once the Task CKD has been created, the user has access to it via a Browse facility which displays one or more keywords and allows the user to 
move back and forth in the file a will; keywords can be copied from the Tast CKD into the appropriate stot of the analysis form. using the usual Windows copy and paste i mmands.

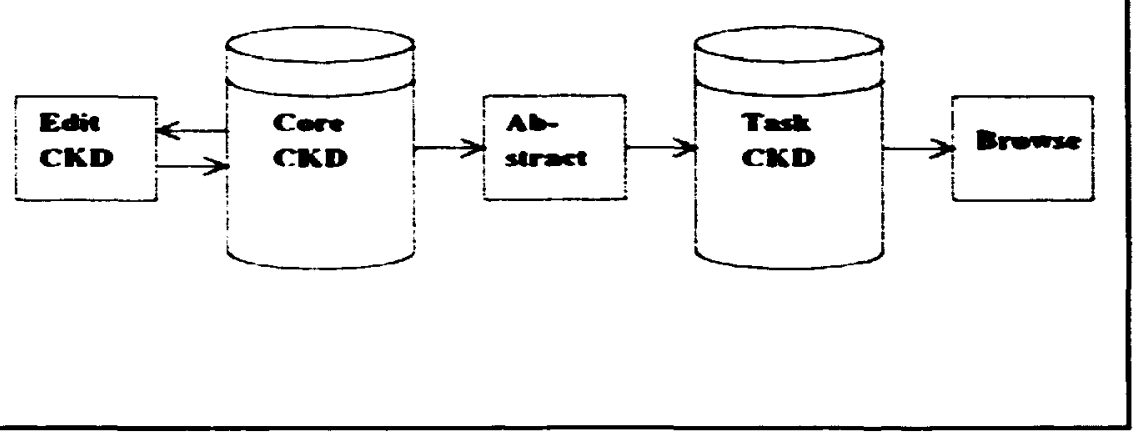

Figure 6. Assembling teywords.

\subsubsection{Partition the plant into sections}

The details of this action vary according to which operating mode has been sel ected; there are, in fact, three possibilities:

a) Automated mode. Here, creation of the plant functional model has in effect partitioned the plant into sections. The first level of decomposition will usually provide sufficient partitioning; however, if this proves to be 100 broad or coarse, functions can be seiccted from the next level of decomposition. Partitions can be selected from any mix of levels of decomposition of the model, provided that it is ensured that the full breadth of the model is covered. E.g. in Figure $7(a)$, the selected functions provide full coverage, whereas in Figure 7 (b) they do not.

b) Manual mode, using a functional model. Here, partitioning is again provided by the functional decomposition and this may be used if so desired.

c) Manual mode, not using a functional model. In this case, no help or guidance is available from the model and the user must partition the plant according to the team's needs. In general, partitions should be such as to be comprehensible and to allow a reasonable amount of time for the team to discuss.

Note that is not recommended that any mixture of manual and model-based partitioning be used as this is a sure recipe for confusion.

Once the plant has been partitioned, analysis proceeds section by section until all have been covered. Forms for the documentation of substance properties and the CHA are given in (Anon. section 4, 1993); modified CHA forms, derived with the objective of a computer based system, are given in the following sections of this document and demonstrated in the appendices. 


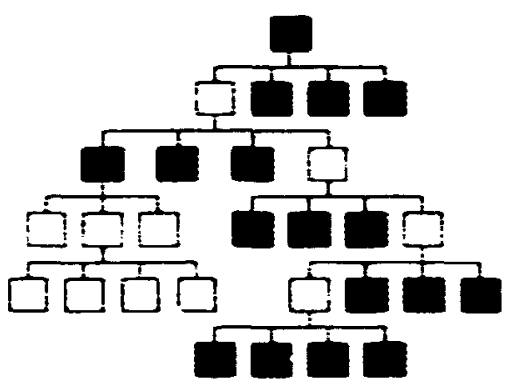

(a)

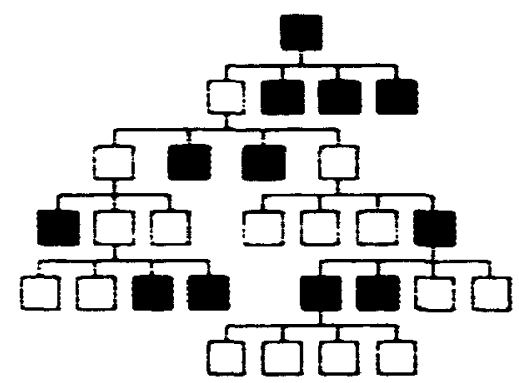

(b)

Figure 7. (a) Valid partitioning. (b) Invalid partitioning.

\subsection{Performing the CHA}

Several formats are proposed for the analysis; Figure 8 shows that suggested for a purely manual analysis, without compuler support, and may be adapted to a word processor or to a printed form.

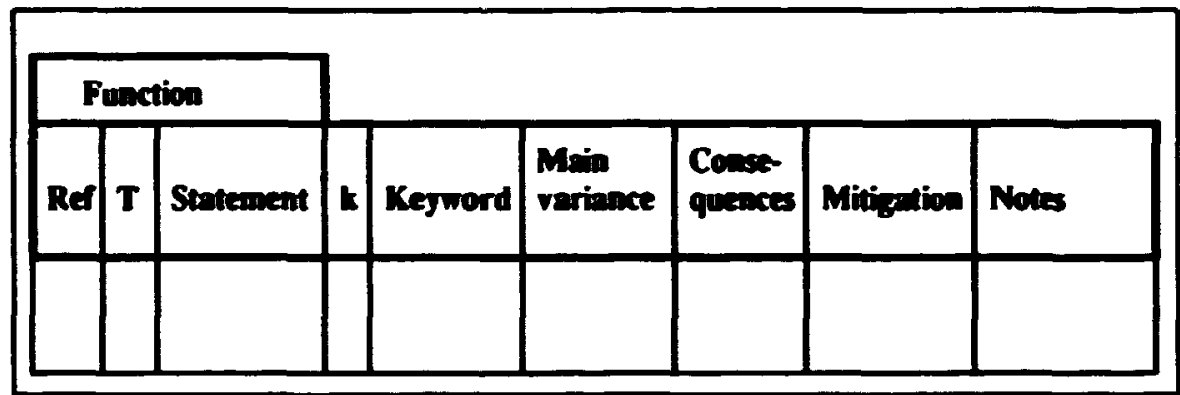

Figure 8. Simple CHA form.

For the TOMHID software, two forms are proposed: one for the plant functional model and the other for the analysis. Figure 9 shows the forma proposed for the functional model.

With the scheme of Figure 9, References would be assigned automatically; one grid is assigned to the Intent statement (of which there can only be one) and an unlimited number of grids exch are assigned to the Methods and Constraints, though only three are displayed. Movement amongst the Methods and Constraints, when there are more than three, is controlled by the scroll-bars, shown to the right of each block. Movement amongst the functions is controlled either by horizontal and vertical scroll bars (not shown in the Figure) or by the model navigator (similar to Figure 7(a)), which is the preferred method.

As noted above, in the automated mode the analysis form is linked to the model display so that whatever functional statement is highlighted on the model, the 


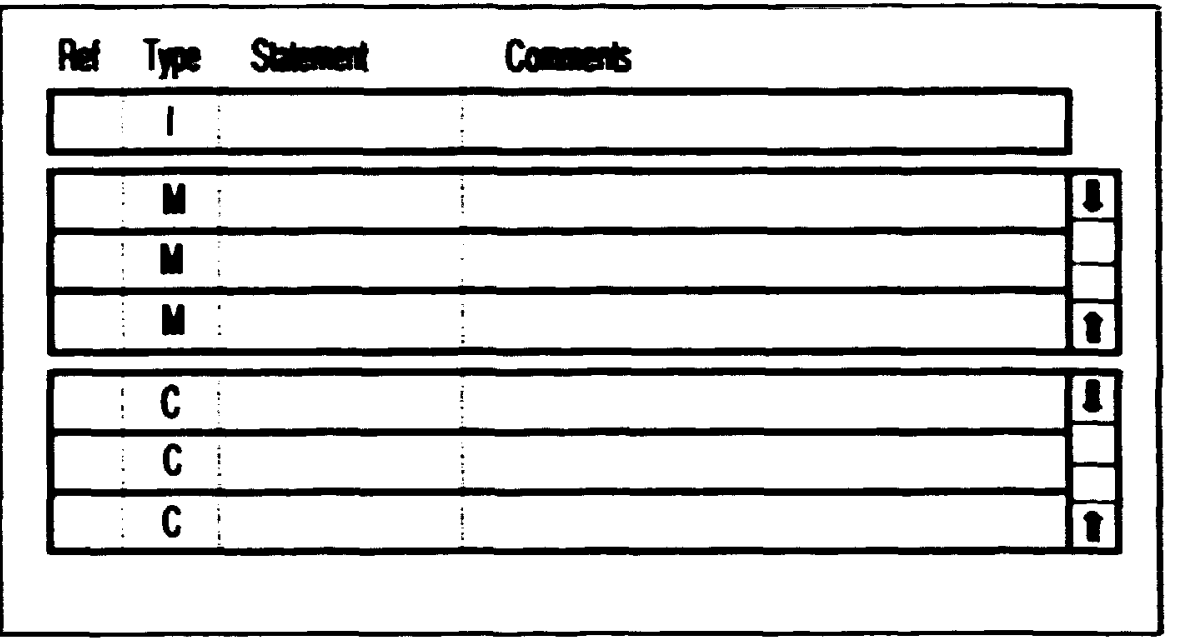

Figure 9. The Function window.

andysis form shows the comesponding andysis. In this case. the Ref. freld of the model form provides the primary reference to the analysis, a second reference being provided by the keyword. since more then one keyword can be applied to a functional stakemem. However. in the manual mode. this lintage does not exist and reference mumbers are supplied by the user. This requires a couprosite format to accommodate the two modes; Figure 10 shows the fomat proposed.

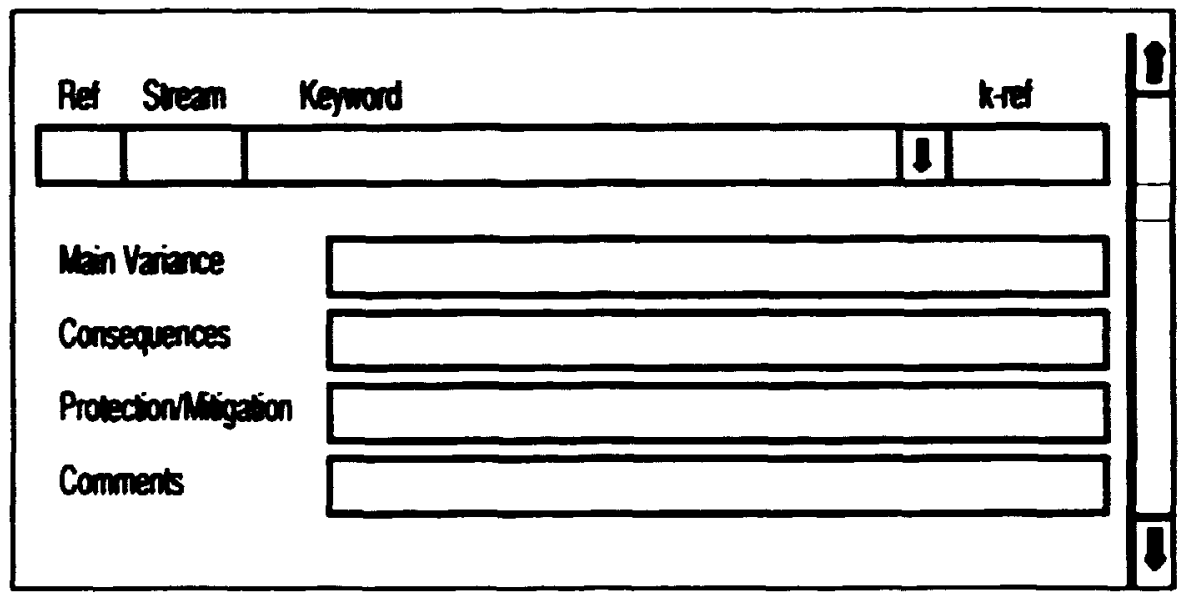

Figure I0. The CHA window.

In the automatic mode, the Ref field merely mimics what is already displayed in the Ref field of the model and the verical scroll har (right) is greyed-out. In manual mode, the Ref lield is automatically incremented whenever a new stream is selected and the vertical scroll bar is activated and used to move up and down amongst the records, which are organised sequentially. Since multiple keywords are allowed, this field is provided with a drop-down box, so that the keywords can be seen and selected. The fields of the three formats are summarised as follows:

- Ref field provides a reference to the record. In the functional model, references are allocated automatically, using the scheme as explained in paragraph 3.3 .1 of this document. Altematively, in manual mode, the same scheme is applied in the model (if used) bot the Ref. field of the analysis is numbered sequentially as records are added. 
- I. An enary in this field indicanes the Type of the following stonesnem. with the

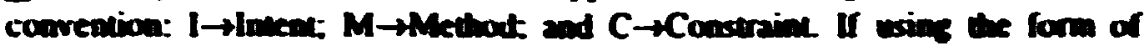

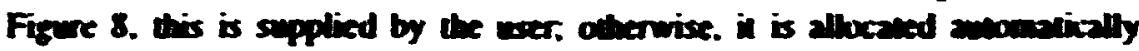

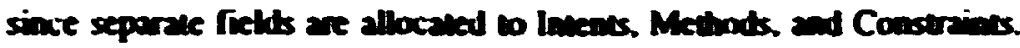

- Sireren this has been includal in the compenertbesed method as an option; it need not be used but it is felt that in can be wefful wo have a cross reference to the substance list.

- Stevemen describes the Invem, Method or Constraint wo which in refers. Since no operations are actually performed on the stotensents, their format and combent

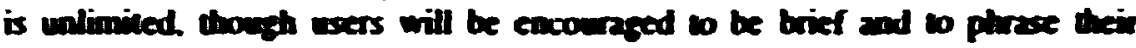

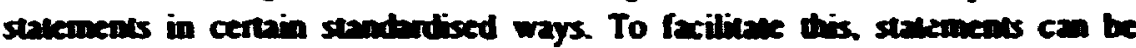
collected and assigned to a function dictionary where they can be examined and re-used so as to promole a consistera style.

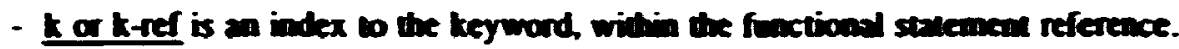
There may be moliple beyworts applied to the stocenen: hese are referenced by leners a, b. $c, 2$.

- Kerword this is the teyword selected from the tast CHA keyword derbase as described in 3.2.1. above. Applying the What if...? privipip by nezation of $b$ renes and Constraines as described in (Anon. section 6.2. 1993) suspests that the first keyword in these two calcgories should always the the word "NoT'.

- Main varizace, this details the main effects inferred from applying the keyword to the function stalement.

- Conseruences. the major consequences which could arise from the main variance.

- Mitization. any factors which exist to mitigate the identified consequences. If fackors are identified which shondd exist (bot are absent) these stould abso be reconded.

- Noles and Comments, any comments entered during construction of the modet are carried fonward into this section. Further moles are added as required.

With the forms and looks described above, several options are aveilath for performing the actual CHA.

\subsubsection{CHA witbout computer support}

a) Keywords are taken from a prepared list and applied to each selecied plant section in tum. By discussion amongat the team. this is used to generate a Main Variance on the analysis form.

b) Each item of equipment is checked against the Equiponent Dala Base (EDB) for known harards. Using the item name as keywnod, variances are reconded from the datahase.

c) Identify the consequences of exch main varienca. 


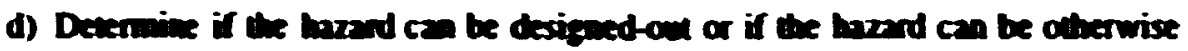
reduced or etiminaned.

c) Deterwise any compots or minigation

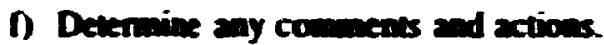

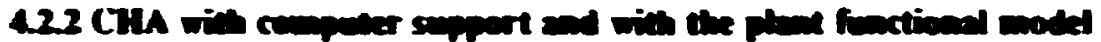

a) Perform a What if.? andysis by megring each hoon Method and Constrain of the model. l.e. by asting: What if this losed (Method or Coustraina) is not

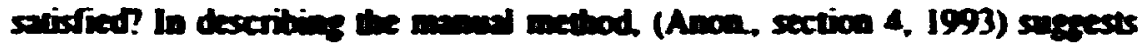
tha a What if.? malysis can be perforived at tis time. Adppting tis idea vo the features offered by the hactionel wodel. a simibr effect can obtained by

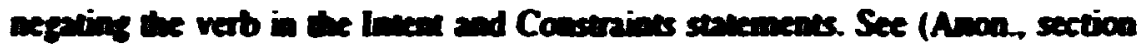
6.2. 1993). Use the resulis of this sep io geverate a Main Variance on the

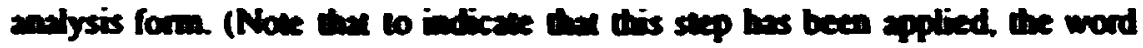
'NOT' stould be inened in the Keywoed colveral.

b) Apply the CHA keywords to each Inean. Method. and Constrint in the model. Keyworts are then from the Tast-CKD and applied to each sturement in turn. This is atso wed to generite a Main Variance on the analysis form.

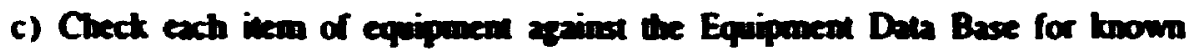
haxands. Using the inem mane as keyword, record any variances.

d) Ideniify the Consequences ach Main Variance.

e) Determine if the harard can be designed-out or if the hazand can be otherwise reduced or eliminoned.

n) Determine any controls or mitigation.

8) Determine any comments and actions. (Note that if any comments were generated during the constrection of the functional model, these will be brought forward into the fimal repon form though during the analysis they will be displayed at their point of origin.)

\subsection{Supporting databases}

In the following the databesses required for a TOMHID CHA - along with the functions supponted - is presented. These functions are detailed in (Davies \& Whetton. 1993) and the sofiware will be further developed in WP4 and WPS and therefore. the discussion here is limited to the usage and contents of the databases. Databases listed in regular type are required for a TOMHID CHA, those in italic type are optional.

- Core Key Words: The Core Keyword Database (CKDB) will consist of primary and secondary keywords. As initial set of keywords is given in the report on WP2. (Anon..1993) and other keywonds will no doubt be added as the project progresses. In rough. round figures, storage will be provided for a maximum of 1,000 primary keywords, with an average of 5 secondary keywords and a maximum of 20 secondary keywords per primary. l.e. 5,000 records total. These 
keywords are used to generate the Task Keyword Database; consequently it has been decided that material cannot be deleted from this database without great difficulty, though keywords can be added at any time. Thus, with use, the database will become ever richer.

- Task Key Words: The Task Keyword Database (TKDB) will always be a subset of the LKDB. As such, it seems unlikely that a TKDB would ever contain more than 100 keywords; therefore a typical TKDB will have, as a maximum, 500 records. These keywords are used directly in the analysis and, although it is possible to have up to a hundred such keywords, it is unlikely that a typical analysis will use more than twenty.

- Equipment: The equipment database contains details of common process equipment, including application diagrams and known characteristics and hazards. It is planned that this database will contain a mixture of text and graphics but that only hazard information in text form can be pasted to the Main Variance and Consequences fields of the analysis form.

- Operations: This optional facility would be a database of basic operations such as fill, empty, lift, observe, etc. as described in section 3.5.1.

- Management Issues: This optional facility would be a database of management issues such as system climate, organisational structure, etc. as described in section 3.5.2.

- Functions: Eventually, as one of the benefits of the functional method, a database of functions would be developed. This would consist of functional models containing the generic portions of models which had previously been created.

- Scenario: This is envisaged as being similar to the database of functions, but concentrating on generic portions of management and operational models.

- Method Dictionary: From the functions database, a dictionary of standard methods can be extracted and then used to promote greater consistency in the analyses.

- Constraint dictionary: From the functions database, a dictionary of standard constraints can be extracted and then used to promote greater consistency in the analyses.

\subsection{Supporting analyses}

Three supporting analyses are planned for TOMHID : Concept Sociotechnical System Review (CSSR), Preliminary Consequence Analysis (PCA), and Short-Cut Risk Assessment Method (SCRAM); these are outlined in the following paragraphs, further details being given in Ref. (Anon., 1993).

\subsubsection{Concept Socio-technical System Review (CSSR)}

The Concept Safety Review ueeds to consider both the Sociotechnical System of which the plant is to be a part and the hazards presented by the plant. Suggested keywords for use during the initial stage of this socio-technical system review 
which are specifically directed at safety factors are listed in the Tables of (Anon., section 4.2, 1993).

It is emphasised that this is a review stage and consequently it is important not to get involved in detailed discussion but to highlight possible problem areas. The aim is to generate major variances caused by the new plant at a particular location for further study. If the review is to be carried out for an expansion of an existing plant it may be a good time to highlight areas giving problems possibly with the aim of getting the topic accepted for the Company's Safety Improvement Programme.

\subsubsection{Preliminary Consequence Analysis (PCA)}

A Preliminary Consequence Analysis of Major Incidents examines the impact of what might occur on a particular process plant. It is usually carried out as soon as a description of the process flow diagram is available. If the site is to be selected it may be done very early and such a study may well only consider pipe breaks and common leaks. The analysis can be carried out following Critical Examination before a decision is made to proceed with more extensive design. Although here the emphasis is on plant it is necessary to do similar studies on the transport of raw materials and products.

In order to ascertain the problems, it is necessary to identify the proposed site and effect an approximate layout of the plant. The basic information required is listed in (Anon., section 4.3, 1993) and some of this information is subsequently transmitted to Regulatory and Planning Authorities when required. The Preliminary Consequence Analysis of Major Hazards will not give an accurate assessment of the frequency of any incident nor the measures used to control or avoid the release. It should however consider ways of dealing with the resulting emergency and instigating the emergency response.

The report should at this stage concentrate on the response to the emergency rather than countermeasures to a specific release. However due attention must be given to the possible escalation of the incident, including escalation as a result of mitigating efforts such as fighting fires.

\subsubsection{Short-Cut Risk Assessment Method (SCRAM)}

Risk is here defined as the Likelihood, L, of a specific undesired event occurring within a given period or in particular circumstances. The likelihood is measured as a frequency per year. The Severity, $\mathbf{S}$, is a measure of the expected consequence of an incident outcome. The Target Risk is defined by the equation

$$
\text { TARGET RISK }=\log _{10} 10^{L}+\log _{10} 10^{s}=\mathrm{L}+\mathrm{S}
$$

where $\mathrm{L}$ is the exponent of likelihood as measured by frequency (a negative value) and $S$ is the severity ranking. The target risk is only acceptable when its value is equal to or less than rero.

To reduce the risk, take measures to:

a) reduce the likelihood of occurrence, which is a measure of the expected probability or frequency of occurrence of an event. 
b) ameliorate the severity of the consequences of its occurrence by appropriate measures, for example the exposure of an individual to a hazardous substance which may not be eliminated by other means might involve measures aimed at prevention of exposure, reduction of emission or exposure and provision of means for dealing with residual risk. 


\section{Conclusions}

From the theoretical work and the two case studies some specific and general experiences and recommendations can be drawn which are summarized below. In this connection it must be remembered that the TOMHID project continues until 1. August 1994 and that the method will be further improved during the work packages $3.2,4$ and 5 .

\subsection{Arising from the batch case study}

From the case study of the batch reactor plant (appendix A) the following points can be noted:

- Functional decomposition: "Methods" and "Constraints" identified as hardware (equipment, chemicals, etc.) are much easier to decompose in a cogent way than objects identified as software (operations, management etc.). Especially "6.0 Manage the operation" and "7.0 Support the operation" cause trouble with respect to selection of an appropriate modelling structure. The structure chosen is to a large extent close to the organisational working structure at the plant and the hierarchical structure of the quality assurance system. (The impact of management and organisational factors on plant safety will be further investigated in work package 3.2).

- Graphical form: Two examples ("1.5.0: Provide MTI" and "7.3.0: Cleaning of MTI/MCF feedsystem") have been worked out to illustrate the application of the graphical form. The numbers in the two forms correspond to the same numbers in the tabular forms. With respect to the graphical presentation form it is important to notice that these forms provide the possibility of clearly showing the interrelations between the different Methods and Constraints related to a specific Intent.

- Level of detail: The batch reactor plant selected as test case is a rather small chemical process plant what concems the size of the plant, the quantity of chemical substances handled and the number of operators directly involved in the production. In the plant functional model the level of detail is high and probably too high for a plant level hazard identification purpose. Therefore it is expected that the degree of detail of plant functional models will be less extensive for other and bigger chemical process plants.

\subsection{Arising from the continuous case study}

Several useful conclusions can be drawn from this exercise (appendix B); they are summarized below, according to subject.

- Overall efficacity: Producing the model, top-down, to the required level of detail and then performing the hazard analysis in bottom-up fashion worked as intended. No great difficulties were encountered and the results seem comparable to a HAZOP to the same level of detail. In fact, hazards such as those associated with security and catalyst handling would probably not have been identified by other methods at this level. 
-Keywords: In general, the existing keywords performed well. However, it is clear that keywords such as EXTREME_WEATHER may be 100 general to guarantee meaningful results without extra imagination on the part of the analysis. Consideration must therefore be given to expanding some of the existing keywords into sub-categories.

Similarly, as noted for Functions 3.1.5, 3.1.7 and 3.1.8. in the example, new keywords are likely to be required to cope with some situations, especially those that concern functions such as maintenance and transport which are outside the immediate domain of the process. It is worth stressing that the development of keywords appropriate to these areas is most important; existing methods of hazard identification do not adequately address these areas and TOMHID offers an opportunity to improve upon this situation.

Standard Methods and Constraints: The existing standard Methods and Constraints performed well, allowing identification of problems which existing methods might not have focused upon so readily. However, some revision is clearly necessary, in particular the need to distinguish clearly between Methods such as Protect from man-made disasters and Protect from incidents in adjacent plant.

Duplicate hazard statements: Performing the hazard analysis 'bottom-up' allowed a more rational treatment of duplicate hazards than when it is performed 'lop-down' and is clearly the preferable procedure. Two general types of duplicate statement have been identified: hazards which are repetitive across functions; and those which are repetitive within a function.

As already noted in WP4 (Davies \& Whetton, 1993), the use of a Hazard Library, stating hazards in a standard form, would allow duplicates to be readily identified by the software so that, where duplicates occur within a function, they can be collected and moved up to the function's Intent and where duplicates occur across functions, they can be tied to the most appropriate place and then cross-referenced at the other places where they occur. Developing from this is the concept of a Specific Hazard Dictionary, a data-base which would be specific to the analysis and would list the identified hazards against where they occur in the analysis. The opposite concept, collecting hazard statements and moving them up to the higher levels, was demonstrated in Functions 5 and 6 of the example, where it appears to be adequate but inconvenient; the proposed solution of a Specific Hazard Dictionary may well have advantages.

Substances list: Although a substance list was not prepared as part of this exercise, it became apparent that in preparing such a list consideration must be given to the 'before and after' states of materials such as catalysts. Other work (Whetton, 1993), (Whetton \& Amstrong) suggests that materials of construction should also be added to the substances list.

\subsection{General}

- Tabular form: The tabular presentation form in which the Concept Hazard Analysis is linked to the plant functional model gives a good overview of the hazards and safety aspects of the different parts of the chemical process plant.

- Standard Methods and Constraints: The use of standard Methods and standard Constraints at a high plant functional level ensures that these important safety aspects are considered and integrated in the analysis. However, experience 
shows that further development of these concepts is required. hefore they can be reliably used as generic TOMHID objects. Work is under development to improve the model for maintenance and this will be reported shortly; further refinements will follow.

- Duplicate hazard statements: The functional hased Concept Hazard Analysis has a tendency to throw up the same problems several times in different places. While such redundancy is not detrimental. some means will have to be found to keep this problem within hounds. In appendix B, two possible approaclues to the problem have heen demonstrated: collecting hazards to a higher level and recording them only at the lowest levels. Neither method seems satisfactory on its own and it seems probable that ad-hoc use of both methods is preferable. 


\section{Acknowledgements}

The authors wish to thank the work performed in the frame of the TOMHID project by our partners at VTT (Technical Research Centre of Finland), Tecsa (ltaly), Joint Research Centre (Ispra), SRD Division of AEA Consulting (United Kingdom) and CIEMAT (Spain).

Furthermore, we wish to acknowledge the CEC programme Major Industrial Hazards for sponsoring the TOMHID project.

\section{References}

Anon. (1993). Conceptual Study of Hazard Identification and Risk Reducing Methods. Final WP2 report. CIEMAT, JRC, Risø, SRD, Sheffield University (editor) \& VTT (deliverer). 284 pp.

Davies, J. \& Whetton C.P. (1993). TOMHID Sofiware Design Document: Sofiware Specification. $22 \mathrm{pp}$.

Kletz, T.A. (1992). Hazop and Hazan. Rugby, IChemE, ISBN 0-85295-285-6.

Malmén, Y., Nissilä, M, Rasmussen, B. \& Rouhiainen, V. (1992). Nordic Experiences and Future Trends for the Preparation of Safety Reports. Nordic Council of Ministers. Nord 1992:46. $180 \mathrm{pp}$.

Wells, G., Wardman, M. \& Whetton, C.P. (1993). Preliminary safety analysis. J.Loss Prev. Process Ind., 6, 47-60.

Whetton, C.P. (1993). Sneak Analysis of Process Systems. Trans IChemE, Vol 71, Part B, August 1993. pp 169-179.

Whetton, C.P., and W. Armstrong. Sneak Analysis Applied to Batch Processes. Joumal of Hazardous Materials. Publication details to be announced. 


\section{A Case study of a batch reactor plant}

\section{A.1 Introduction}

This appendix contains one batch reactor example performed on the principles of the TOMHID tool described in the main report. The intention is to illustrate and discuss how the concept and the principles can work in practice. First, the technical plant configuration is shortly described together with remarks and results on the practical implementation of the functional modelling principles and the Concept Hazard Analysis on the batch reactor plant. Second, enclosed to the appendix the tabular forms and a few graphical examples can be found containing the functional plant decomposition and the hazard identification. The main conclusions and recommendations from this example are summarized in chapter 5 of the main report together with the corresponding results from the continuous process plant example.

\section{A.2 Short description of the batch reactor plant}

The selected batch reactor example is the previous production of the herbicide PMP (Phenmedipham) at the Danish company Kemisk Værk Køge A/S (KVK). The production of PMP at KVK was abandoned in 1989, the consequence of a production reorganisation at $\mathrm{KVK}$. Thus, due to this reorganisation is must be emphasized that the activities at KVK no longer involve quantities of hazardous substances which according to the Seveso Directive may lead to major-accident hazards.

The following plant description is very short. A more detailed and comprehensive safety report can be found in Malmen et al (1992).

Information about the involved chemical substances and their combustion products

For the production in question the final product is Herbaphene. The chemical composition of Herbaphene is PMP and auxiliary substances dissolved in isophoron. In the production the following chemical substances are involved: $m$-aminophenol (MAP), methyl chloroformate (MCF), m-tolyl isocyanate (MTI), 28\% $\mathrm{NaOH}$ solution and $30 \% \mathrm{HCl}$ solution. The formulation process further involves isophoron and for cleaning of equipment solvesso (trimethylbenzene) and varsol (solvent naphtha) are used.

From a safety point of view the most essential chemical substances are:

- MCF: (Formula: $\mathrm{ClCOOCH}_{3}$ ). Colourless or light yellow volatile liquid (b.p.

$71^{\circ} \mathrm{C}$ and high vapour pressure at $20^{\circ} \mathrm{C}$ ) with vapours extremely imitating to eyes. MCF is classified as "poisonous" (TLV: $0.2 \mathrm{mg} / \mathrm{m}^{3}$ ). Even relatively low concentrations of MCF can be highly toxic to human beings upon inhalation (pulmonary edema). MCF is inflammable and explosion hazards arise when MCF vapours are mixed with air. Vapours may travel to a source of ignition and flash back. Water and humid air can hydrolyse MCF under the formation of toxic and corrosive fumes. MCF is very dangerous when exposed to heat sour- 
ces, sparks, flames or oxidizers. Combustion products: Phosgene $\left(\mathrm{COCl}_{3}\right)$ and toxic fumes of $\mathrm{Cl}$.

- MTI: (Formula: $\mathrm{OCN} . \mathrm{C}_{6} \mathrm{H}_{4} \cdot \mathrm{CH}_{3}$ ). Colourless or light yellow and nammable liquid with a characteristic smell. MTI has a relatively high boiling point, $189^{\circ} \mathrm{C}$. MTI vapours have a high density, 3.7. MTI is classified as "extremely poisonous" (TLV: $0.035 \mathrm{mg} / \mathrm{m}^{3}$ ) and it is irritating to eyes, skin and respiratory organs. Combustion products: Oxides of nitrogen $\left(\mathrm{NO}_{2}\right)$.

- MAP: (Formula: HO.C $\mathrm{C}_{6} \cdot \mathrm{NH}_{2}$ ). MAP is a solid substance which smells like phenol (b.p. $164^{\circ} \mathrm{C}$, m.p. $121-122^{\circ} \mathrm{C}$ ). MAP is soluble in water. MAP is classified as "injurious to health". Combustion products: Oxides of nitrogen ( $\mathrm{NO}_{\mathbf{z}}$ ).

- PMP: (Formula: $\mathrm{C}_{16} \mathrm{H}_{16} \mathrm{~N}_{2} \mathrm{O}_{4}$ ). Pure PMP forms colourless crystals (m.p. 140$144^{\circ} \mathrm{C}$ ). No fire or explosions hazards exist. PMP is not classified. Combustion products: Fumes are injurious to health.

\section{Quantities of chemical substances involved in the different activities}

The PMP synthesis is carried out as a batch process. The process time is 8 hours per batch and the capacity is $590 \mathrm{~kg}$ PMP per batch. MCF and MTl are stored in 200 litre drums inside covered by a plastic coating. The maximum storage size is limited to 6 tons of each substance. Isophoron is stored in a 20 tons container. MAP is stored in sacks and the average size of the MAP storage is 5 tons.

\section{Information about processes and chemical reactions}

The PMP plant consists of two stirred batch reactors (tank A and B). The raw materials MCF and MTI are automatically added to tank $A$ through a special piping installation. A thin layer evaporator is installed between tank A and B. A holding tank for the final product (tank C) is connected to tank B. Furthermore, there is a tank for collection of waste water (tank D). The Herbaphene manufacturing can be divided into four steps:

- PMP synthesis: Initially water and MAP are mixed. MCF is added and the intermediate product methyl-N-(3-hydroxyphenyl)-carbamate (MHPC) is formed. This step of the synthesis is carried out at fixed $\mathrm{pH}$ and by addition of ice the temperature is kept at a fixed level. This reaction step is exothermic and if the addition of ice is omitted a temperature increase of $16^{\circ} \mathrm{C}$ will appear. In the second step PMP is formed by a reaction between MTI and MHPC. In the second step $\mathrm{pH}$ is fixed while the temperature will increase slowly. MCF and MTI are added through the special piping installation from the storage drums placed in a small room separated from the rest of the plant. The chemical reactions are:

$$
\begin{aligned}
& \underset{(M C P)}{\mathrm{CH}_{3} \mathrm{OCOCl}}+\underset{(\text { MAP) }}{\mathrm{C}_{6} \mathrm{H}_{4}(\mathrm{OH})-\mathrm{NH}_{2}} \rightarrow \underset{(\text { MHPC }}{\mathrm{C}_{6} \mathrm{H}_{4}(\mathrm{OH})-\mathrm{NHCOOCH}_{3}} \\
& \underset{\text { MHPC) }}{\mathrm{C}_{6} \mathrm{H}_{4}(\mathrm{OH})-\mathrm{NHCOOCH}_{3}}+\underset{(\mathrm{MTM})}{\mathrm{C}_{6} \mathrm{H}_{4}\left(\mathrm{CH}_{3}\right)-\mathrm{NCO}} \rightarrow \\
& \mathrm{C}_{6} \mathrm{H}_{4}\left(\mathrm{CH}_{3}\right)-\mathrm{NHCOO}_{(\mathrm{PMP})}-\mathrm{C}_{6} \mathrm{H}_{4}-\mathrm{NHCOOCH}_{3}
\end{aligned}
$$

- Isophoron formulation: When the synthesis is finalized $\mathrm{pH}$ is lowered and PMP is dissolved in isophoron.

- Drying of the isophoron phase: The isophoron is pumped through the thin layer evaporator and by contact with hot air the water content of the isophoron phase is lowered. 
- Addition of auxiliary substances: Auxiliary substances are added to the isophoron solution and isophoron is added adjusting the mixture to the Herbaphene requirements. Finally, the Herbaphene drums are filled with the product.

\section{The overall structure of the PMP plant}

The overall structure of the PMP is presented in table $A l$ and in figure Al the flow diagram of the PMP production can be found.

Table AI. Overall structure of the PMP plant

\begin{tabular}{|c|c|}
\hline $\begin{array}{l}\text { Provide raw } \\
\text { materials }\end{array}$ & $\begin{array}{l}\text { - Provide MAP, MCF, } \mathrm{HCl}, \mathrm{NaOH}, \mathrm{MTI} \text {, isophoron, } \mathrm{NaCl} \text {, auxitiary } \\
\text { substances }\end{array}$ \\
\hline Pre treament & $\begin{array}{l}\text { - The batch reactor is filled with water. } \\
\text { - Addition of MAP. } \\
\text { - Conditioning of } \mathrm{pH}(\mathrm{HCl}) \text {; conditioning of temperature (ice). }\end{array}$ \\
\hline Peacting & $\begin{array}{l}\text { - Addition of MCF. } \\
\text { - }(\mathrm{NaOH} \text { ): conditioning of tomperature (ice). } \\
\text { - Increase of pH (NaOH). } \\
\text { - Addition of MTI. } \\
\text { Reacting MTI and MHPC to PMP in water; conditioning of pH (MCl, } \\
\text { NaOH). }\end{array}$ \\
\hline Post treatment & $\begin{array}{l}\text { - Decrease of pH }(\mathrm{HCl}) \text {. } \\
\text { - Addition of isophoron and } \mathrm{NaCl} \text {. } \\
\text { - Separation of water and isophoron phases. } \\
\text { - Drying of the isophoron phase (thin layer evaporator). } \\
\text { adjustment of product to Herbaphene requirements. }\end{array}$ \\
\hline Storage & - Packing and storage of the product Herbaphene. \\
\hline $\begin{array}{l}\text { Auxiliary } \\
\text { activities }\end{array}$ & $\begin{array}{l}\text { - Maintenance, repair and cleaning of process equipment. } \\
\text { - Treatment of solid waste, waste water and exhausted air. } \\
\text { - PMP control systems (including sequence control, alarm systems } \\
\text { - Ptc.). } \\
\text { PMP emergency system. }\end{array}$ \\
\hline
\end{tabular}

\section{Information relating to the organisation and the management}

The organisation of the PMP activities at KVK is split up into three levels.

Strategic level:

- Managing director responsible for performance of the primary safety and quality goals for the enterprise.

- Technical director responsible for performance of the safety and quality goals for tise PMP production.

- Head of quality assurance department responsible for:

* development and implementation of the quality assurance system

* performance of quality assurance tests

* analysis of deviations from expected quality

* information to the board of directors about the implementation of the quality assurance programme. 


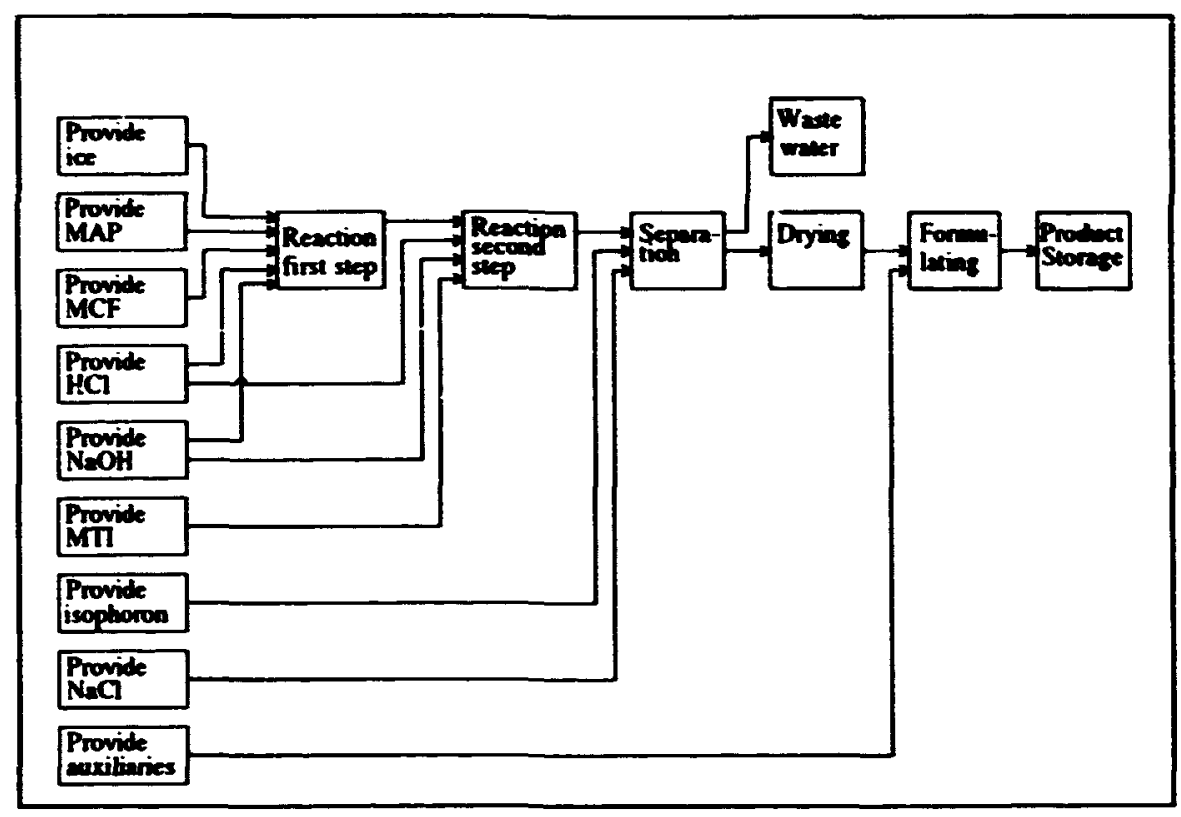

Figure AI. Flow diagram - PMP production.

- Safery officer responsible for promoting safety at KVK. The safety organisation comprises:

* the safety officer

* a safety, health and welfare committee with 5 members

* 33 safety groups.

Furthermore, an industrial doctor is employed.

Tactical level:

At the tactical level there are three managers: Head of production, head of maintenance and an engineer responsible for the electrical installations. Each of these is responsible for working out procedures, instructions and manuals necessary to meet the safety and quality goals in accordance with the principles laid down in the strategic plan.

Operational level:

For each of the three working areas (production, maintenance and electrical facilities) 2 managing engineers are responsible for:

- that all employees in his group are informed about instructions and procedures

- that manuals and instructions are obeyed

- that the necessary revisions of technical and administrative instructions and information are initiated and implemented

- that all employees possess sufficient training and experience

- that the activities in his area are coordinated with the other activities at KVK

- that tests initiated by the quality assurance department are accomplished.

\section{Quality assurance system}

A quality assurance system has been developed in relation to the PMP production. The QA handbook contains a description of the primary principles for quality assurance at KVK. Routines for construction, control, operation, maintenance, repair, emergency etc. are described in manuals. Finally, series of instructions contain detailed descriptions of the specific job functions. 


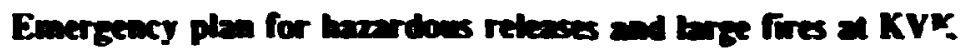

Incidents involving MCF or MTI have been incegraed in the general emergency progranme of KVK. It must be stressed that the general emergency plan comprises incidents and accidents that might octur in connection with other KVK $\propto$ tivities. The following incidents and alarms are covered by the emergency plan:

1. Local emersency: Minor incidents limited to a production unit.

2. Intemal emergency: Major incidents causing inconveniences outside a production area but without effects outside the area of $\mathrm{KVK}$.

3. Exiemal emergency: Major hazards.

\section{A.3 PMP plant functional model}

As mentioned earlies the functional modelling of the PMP plan has been carried out by use of the tabular form. To illustrate the application of the graphical form two examples have been prepared.

The overall plant Intent has been defined as Produce PMP. The Methods and Constraints related to the overall Invent has been defined on basis of the overall plant structure (table Al) and the lists of standard methots and standard constraints (table I and 2 of the main report). This has resulted in the following first level objects in the functional model of the PMP plant:

$\begin{array}{ll}\begin{array}{l}\text { Intent } \\ \text { by }\end{array} & \text { Produce PMP } \\ \text { Method } & \text { Provide raw materials } \\ \text { Method } & \text { Pre-treatment } \\ \text { Method } & \text { Reacting } \\ \text { Method } & \text { Prost-ureatment } \\ \text { Method } & \text { Store final product } \\ \text { Method } & \text { Manage the operation } \\ \text { Method Support the operation } \\ \text { with }\end{array}$

Constraint Protect the environment from the plant

Constraint Protect the plant from the environment

Each of these Methods or Constraints have been further decomposed unil an appropriate level of details has been achieved. During the functional modelling it is important to keep in mind that the main reason for canying out the functional modelling is the subsequent hazard identification and therefore the functional modelling has to end up with methods and constraints suitable for the keywords of the Concept Hazard Analysis.

\section{A.4 Concept Hazard Analysis}

The relevant keywords considered in relation to the PMP plant are listed below. These kevwords have been sclected on basis of our knowledge ahout the technical configuration of the PMP plant and the general list of keywords (Wells, Wardman \& Whetton, 1992) and (Anon. 1993). 


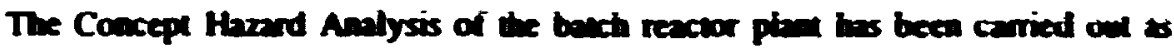
described in section 4.21; i.e. CHA withoul compener sopport.

Selected teywonds:

- Namables: ignidioar fire

- chemicals: coxic: highly toxic: extremely poisonous; corrosion

- healh havads: chemical concact: exposure

- reactions: mildly exothermix

- process conditions: cemperalure: pH

- equipment problems: capecity. pipelines; betow, dran; feedsystem; puap; separeor, eveporetor, formibion

- mode of operation: lext and mintenanace:

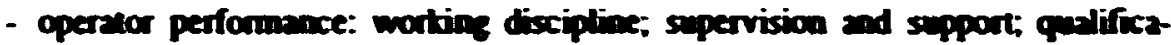
tions and education; emergency exercises and urinias

- procedures: worting practice

- system climare: conporite culbure; peblic relations

- Organisonicon: decision-moline biernechy

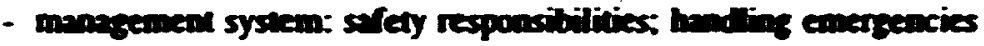

- commenication inciden reporting and imestigations information quality

\section{A.5 Results}

\section{Ideatifed poteatiel horeds}

The most essemial hazard is dispersion and combustion of the extremely poisonous substrnce MTI. Healh haxarts may abo exist in rebrion to other chemical substances and here special emphasis mast be laid on dispersion and combestion of MCF.

Ideatifed somres of herents and the conditions mader which an accideat conde oxer

During handling or incernal uransport drums containing the loxic chemical sobstances may be damaged, and this may case a leat of a loxic chemical. Toxic chemicals may be released during repair, mainenance and cleaning. e.g. if a drem is not fully emptied or the feed system is drained insufficienly. A fire in one of the chemical storages may be initialed if highly inflammoble substances are erroneously placed in the storage. Furthermore, releases and spills during processing may be considered caused by nuptures, leakages and overfilling.

\section{Ascassment of accident consequences}

This may include dose/concentration assessment covering the following scenarios:

- evaporation of toxic gases from a pool

- emission of toxic fumes from a pool fire

- emission of toxic funes from a large fre in a chemical storage.

\section{Sefety measures}

The safety level at the PMP plant is high. both technically and organisationally. Several safety measurea have heen implemented and installed. thus reducing the incident frequencies and the incident consequences. The precautions cover all $x$ - 


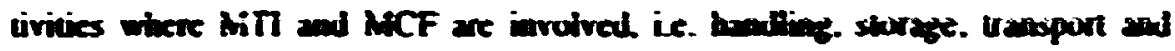
processing. The mos ieponand salety measures are:

- inplementotion of lie quality assurance systema

- implementation of the PMP energency phan.

The impleneabation of the emeryency phan has resalved in rety good pussibilities and condivions for efficien prevention and banding of incillents. The established

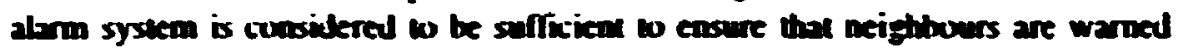

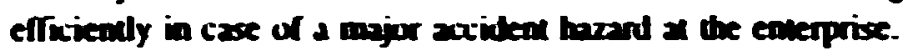




\begin{tabular}{|c|c|c|c|c|c|c|c|c|}
\hline \multicolumn{3}{|r|}{ FUNCTION } & \multicolumn{6}{|c|}{ HAZARDOUS PROCESS CHARACTERISTICS - PMP PLANT } \\
\hline REF & $\mathbf{T}$ & DESCRIPTION & $\mathbf{k}$ & KEYWORD & MAIN VARIANCE & CONSEQUENCES & MITIGATION & NOTES \\
\hline 18. & . & 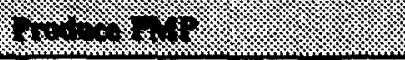 & & & & & & \\
\hline 1 & $\mathbf{M}$ & Provide raw materials & & See 1.0 & & & & \\
\hline 2 & $\mathbf{M}$ & Pre-treatment & & See 2.0 & & & & \\
\hline 3 & $\mathbf{M}$ & Reacting & & See 3.0 & & & & \\
\hline 4 & $\mathbf{M}$ & Post-treatment & & See 4.0 & & & & \\
\hline 5 & $\mathbf{M}$ & Store final product & & See 5.0 & & & & \\
\hline 6 & $\mathbf{M}$ & Manage the operation & & See 6.0 & & & & \\
\hline 7 & $\mathbf{M}$ & Support the operation & & See 7.0 & & & & \\
\hline 8 & C & $\begin{array}{l}\text { Protect the environment from } \\
\text { the plant }\end{array}$ & & See 8.0 & & & & \\
\hline 9 & c & $\begin{array}{l}\text { Protect the plant from the en- } \\
\text { vironment }\end{array}$ & & See 9.0 & & & & \\
\hline$\sqrt{2}$ & 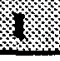 & 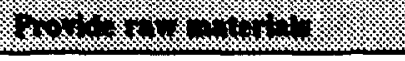 & 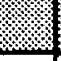 & & & ২: & স্যে & \\
\hline 1.1 & $\mathbf{M}$ & Provide MAP & a & Chemicals: Toxic & Release $\rightarrow$ ignition & Emission of $\mathrm{NO}_{\mathbf{x}}, \mathrm{MAP}$ & $\begin{array}{l}\text { Handling and storage } \\
\text { procedures }\end{array}$ & Check health effects \\
\hline 1.2 & $\mathbf{M}$ & Provide MCF & a & Flammables & Release $\rightarrow$ fire & $\begin{array}{l}\text { Emission of } \mathrm{COCl}_{2}, \mathrm{Cl} \text {. } \\
\text { MCF }\end{array}$ & $\begin{array}{l}\text { Handling/cleaning/storage } \\
\text { prncedures }\end{array}$ & Check health effects \\
\hline & & & b & $\begin{array}{l}\text { Chemicals: Highly } \\
\text { toxic }\end{array}$ & Rejease $\rightarrow$ evaporation & Emission of MCF & QA-system & \\
\hline 1.3 & $\mathbf{M}$ & Provide $\mathrm{HCl}$ & a & Chemicals: Corrosion & Release & Conrosion & $\begin{array}{l}\text { Handling and storage } \\
\text { procedures }\end{array}$ & \\
\hline 1.4 & $\mathbf{M}$ & Provide $\mathrm{NaOH}$ & $\mathbf{a}$ & Chemicals: Corrosion & Release & Corrosion & $\begin{array}{l}\text { Handling and storage } \\
\text { procedures }\end{array}$ & \\
\hline 1.5 & $\mathbf{M}$ & Provide MTI & a & $\begin{array}{l}\text { Chemicals: Extremely } \\
\text { poisonous }\end{array}$ & Release $\rightarrow$ ignition & Emission of MTI, $\mathrm{NO}_{\mathrm{z}}$ & $\begin{array}{l}\text { Handling/cleaning/storage } \\
\text { procedures } \\
\text { Emergency system } \\
\text { QA-system }\end{array}$ & $\begin{array}{l}\text { Check entrainment of } \\
\text { MTI in case of fire } \\
\text { Check health effects }\end{array}$ \\
\hline 1.6 & $\mathbf{M}$ & Provide isophoron & a & Flammables & Release $\rightarrow$ fire & Fire, domino effects & Segregation by distance & Fire hazard moderate \\
\hline
\end{tabular}




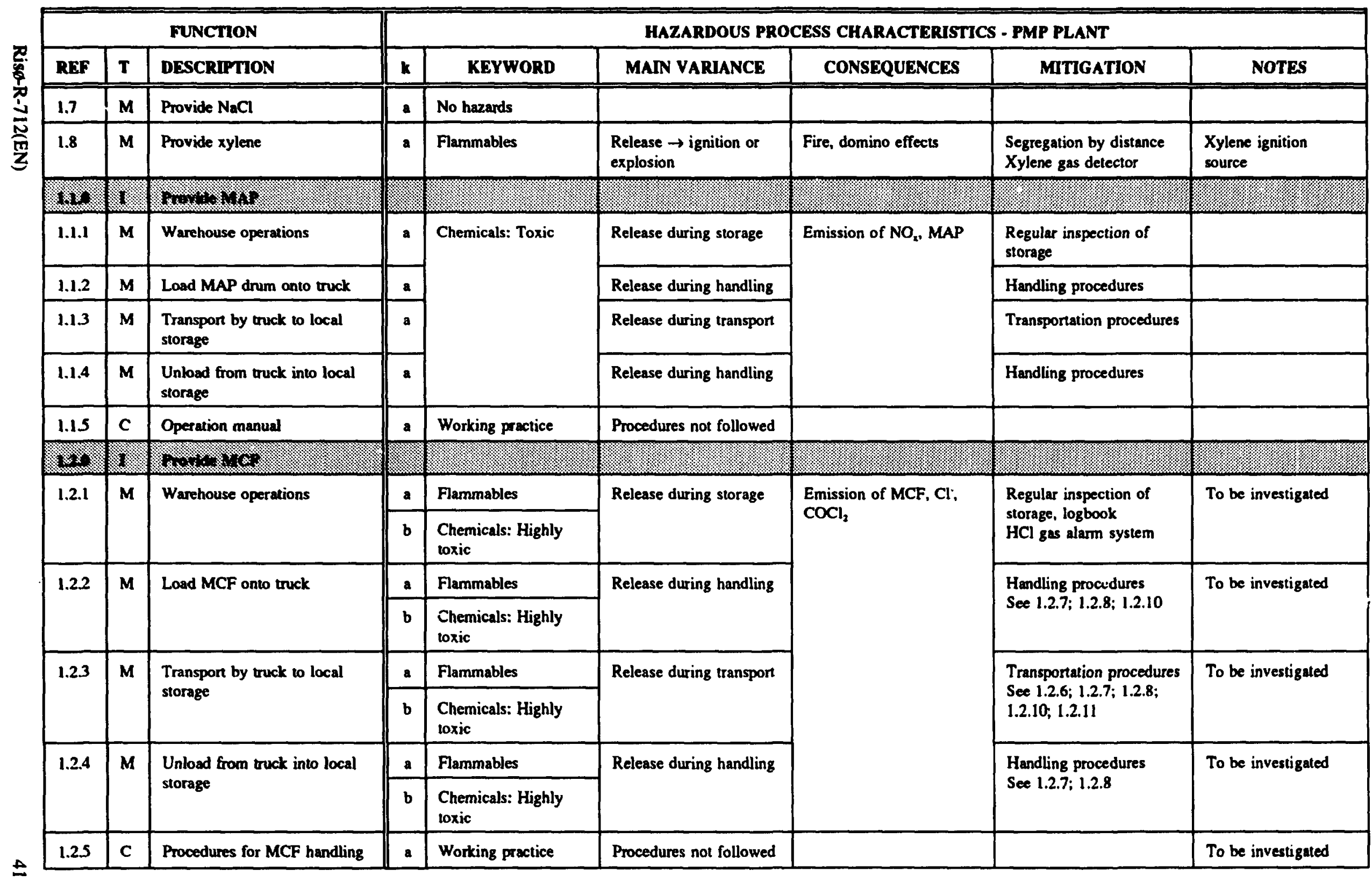




\begin{tabular}{|c|c|c|c|c|c|c|c|c|}
\hline \multicolumn{3}{|r|}{ FUNCTION } & \multicolumn{6}{|c|}{ HAZARDOUS PROCESS CHARACTERISTICS - PMP PLANT } \\
\hline REF & $\mathbf{T}$ & DESCRIPTION & k & KEYWORD & MAIN VARIANCE & CONSEQUENCES & MITIGATION & NOTES \\
\hline 1.2 .6 & C & $\begin{array}{l}\text { Establish restricted roule for } \\
\text { transport of MCF }\end{array}$ & a & Working discipline & $\begin{array}{l}\text { Route not established } \\
\text { properly }\end{array}$ & & & To be investigated \\
\hline 1.2 .7 & C & $\begin{array}{l}\text { Close supervision of all move- } \\
\text { ments of MCF is required }\end{array}$ & $\mathbf{a}$ & $\begin{array}{l}\text { Supervision and sup- } \\
\text { port }\end{array}$ & Not performed properly & & & To be investigated \\
\hline 1.2 .8 & C & $\begin{array}{l}\text { Radiotelephone must be avail- } \\
\text { able during the MCF transpon }\end{array}$ & a & $\begin{array}{l}\text { Supervision and sup- } \\
\text { port }\end{array}$ & Not performed properly & & & To be investigated \\
\hline 1.2 .9 & $\mathbf{C}$ & $\begin{array}{l}\text { HCl gas alarm system in cen- } \\
\text { tral storage }\end{array}$ & $\mathbf{a}$ & Test and maintenance & $\begin{array}{l}\text { Malfunction of alarm } \\
\text { system }\end{array}$ & Undetected fire or release & & $\begin{array}{l}\text { Check maintenance } \\
\text { procedures }\end{array}$ \\
\hline $\begin{array}{l}1.2- \\
.10\end{array}$ & c & $\begin{array}{l}\text { Absorting malerial, slaked } \\
\text { lime and extinguisher available } \\
\text { at central storage }\end{array}$ & $\mathbf{a}$ & Availability & Not available & $\begin{array}{l}\text { Escalation of conse- } \\
\text { quences in case of an } \\
\text { accident }\end{array}$ & & $\begin{array}{l}\text { Check routine inspec } \\
\text { tion of accident pro- } \\
\text { tective measures }\end{array}$ \\
\hline $\begin{array}{l}1.2- \\
.11\end{array}$ & C & $\begin{array}{l}\text { Fire alarm and gas alarm } \\
\text { system at local storage (PMP } \\
\text { control system) }\end{array}$ & $\mathbf{a}$ & Test and maintenance & $\begin{array}{l}\text { Malfunction of alarm } \\
\text { systems }\end{array}$ & Undetected fire or release & & $\begin{array}{l}\text { Check maintenance } \\
\text { procedures }\end{array}$ \\
\hline 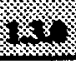 & 13. & 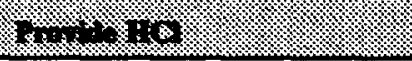 & & & & & & \\
\hline 1.3 .1 & $\mathbf{M}$ & Warehouse operations & a & \multirow[t]{4}{*}{ Chemicals: Corrosion } & Release during storage & \multirow[t]{4}{*}{$\begin{array}{l}\text { Chemical exposure, cor- } \\
\text { rasion }\end{array}$} & $\begin{array}{l}\text { Regular inspection of } \\
\text { storage }\end{array}$ & \\
\hline 1.3 .2 & $\mathbf{M}$ & Load $\mathrm{HCl}$ drum onto truck & a & & Release during handling & & Handling procedures & \\
\hline 1.33 & $\mathbf{M}$ & $\begin{array}{l}\text { Transpon by truck to local } \\
\text { storage }\end{array}$ & $\mathbf{a}$ & & Release during transport & & Transportation procedures & \\
\hline 1.3 .4 & $\mathbf{M}$ & $\begin{array}{l}\text { Unload from truck into local } \\
\text { storage }\end{array}$ & a & & Release during handling & & Handling procedures & \\
\hline 1.3 .5 & c & Operation manual & $\mathbf{a}$ & Working practice & Procedures not followed & & & \\
\hline 83 & 13 & 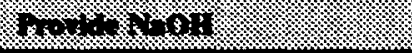 & . & (1) & ঝ: & & & \\
\hline 1.4 .1 & $\mathbf{M}$ & Warehouse operations & a & \multirow[t]{3}{*}{ Chemicals: Corrosion } & Release during storage & \multirow[t]{3}{*}{$\begin{array}{l}\text { Chemical exposure, cor- } \\
\text { rosion }\end{array}$} & $\begin{array}{l}\text { Regular inspection of } \\
\text { storage }\end{array}$ & \\
\hline 1.4 .2 & $\mathbf{M}$ & Losd $\mathrm{NaOH}$ drum onto truck & $\mathbf{a}$ & & Release during transpor & & Handling procedures & \\
\hline 1.43 & $M$ & $\begin{array}{l}\text { Transport by truck to local } \\
\text { storage }\end{array}$ & a & & Release during handling & & Transportation procedures & \\
\hline
\end{tabular}




\begin{tabular}{|c|c|c|c|c|c|c|c|c|}
\hline \multicolumn{3}{|r|}{ FUNCTION } & \multicolumn{6}{|c|}{ HAZARDOUS PROCESS CHARACTERISTICS - PMP PLANT } \\
\hline REF & $\mathbf{T}$ & DESCRIPTION & k & KEYWORD & MAIN VARIANCE & CONSEQUENCES & MITIGATION & NOTES \\
\hline 1.4 .4 & $\mathbf{M}$ & $\begin{array}{l}\text { Unload from truck into local } \\
\text { storage }\end{array}$ & $\mathbf{a}$ & & Release during handling & & Handling procedures & \\
\hline 1.45 & C & Operation manual & $\mathbf{a}$ & Working practice & Procedures not followed & & & \\
\hline 180 & ?. & $1.0 .0 .+1.10$ & & & & & & \\
\hline 1.5.1 & $\mathbf{M}$ & Warehouse operaticns & $\mathbf{a}$ & \multirow[t]{4}{*}{$\begin{array}{l}\text { Chemicals: Extremely } \\
\text { poisonous }\end{array}$} & Release during storage & \multirow[t]{4}{*}{ Emission of $\mathrm{NO}_{\mathrm{z}}, \mathrm{MTl}$} & $\begin{array}{l}\text { Regular inspection of } \\
\text { storage, logbook }\end{array}$ & To be investigated \\
\hline 1.5 .2 & $\mathbf{M}$ & Load MTI anto truck & $\mathbf{a}$ & & Release during handling & & $\begin{array}{l}\text { Handling procedures } \\
\text { See } 1.5 .7-1.5 .9\end{array}$ & To be investigated \\
\hline 1.5 .3 & $\mathbf{M}$ & $\begin{array}{l}\text { Transpon by truck to local } \\
\text { storage }\end{array}$ & $\mathbf{a}$ & & Release during transport & & $\begin{array}{l}\text { Transportation procedures } \\
\text { See 1.5.6-1.5.10 }\end{array}$ & To be investigated \\
\hline 1.5 .4 & $\mathbf{M}$ & $\begin{array}{l}\text { Unload from truck into local } \\
\text { storage }\end{array}$ & $\mathbf{a}$ & & Release during handling & & $\begin{array}{l}\text { Handling procedures } \\
\text { See 1.5.7; } 1.5 .8\end{array}$ & To be investigated \\
\hline 1.5 .5 & $\mathbf{c}$ & Procedures for MTI handling & a & Working practice & Procedures not followed & & & To be investigated \\
\hline 1.5 .6 & C & $\begin{array}{l}\text { Establish restricted route for } \\
\text { transport of MTI }\end{array}$ & $\mathbf{a}$ & Working discipline & $\begin{array}{l}\text { Route not established } \\
\text { properly }\end{array}$ & & & To be investigated \\
\hline 1.5 .7 & $\mathbf{c}$ & $\begin{array}{l}\text { Close supervision of all move- } \\
\text { ments of MTI is required }\end{array}$ & $a$ & $\begin{array}{l}\text { Supervision and sup- } \\
\text { port }\end{array}$ & Not performed properly & & & To be investigated \\
\hline 1.5 .8 & $\mathbf{c}$ & $\begin{array}{l}\text { Radiotelephone must be avail- } \\
\text { able during the MTI transport }\end{array}$ & $\mathbf{a}$ & $\begin{array}{l}\text { Supervision and sup- } \\
\text { port }\end{array}$ & Not performed properly & & & To be investigated \\
\hline 1.5 .9 & C & $\begin{array}{l}\text { Absorbing material, slaked } \\
\text { lime and extinguisher available } \\
\text { at central storage }\end{array}$ & $\mathbf{a}$ & Availability & Nol available & $\begin{array}{l}\text { Escalation of conse- } \\
\text { quences in case of an } \\
\text { accident }\end{array}$ & & $\begin{array}{l}\text { Check routine inspec- } \\
\text { tion of accident pro- } \\
\text { lective measures }\end{array}$ \\
\hline $\begin{array}{l}1.5- \\
.10\end{array}$ & C & $\begin{array}{l}\text { Fire alarm and gas alarm } \\
\text { system at local storage (PMP } \\
\text { control system) }\end{array}$ & $\mathbf{a}$ & Test and maintenance & $\begin{array}{l}\text { Malfunction of alarm } \\
\text { systems }\end{array}$ & Undelected fire or release & & $\begin{array}{l}\text { Check maintenance } \\
\text { procedures }\end{array}$ \\
\hline $18 \%$ & (1) & 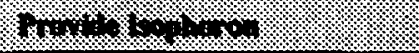 & & & & & & \\
\hline 1.6.1 & $\mathbf{M}$ & $\begin{array}{l}\text { Transport by lorry to local } \\
\text { storage }\end{array}$ & $\mathbf{a}$ & \multirow[t]{2}{*}{ Flammable } & \multirow[t]{2}{*}{$\begin{array}{l}\text { Leakage } \rightarrow \text { release } \rightarrow \\
\text { ignition }\end{array}$} & \multirow[t]{2}{*}{ Fire, domino effects } & & \multirow[t]{2}{*}{ Fire hazard moderate } \\
\hline 1.6 .2 & $\mathbf{M}$ & Unload isophoron container & $\mathbf{a}$ & & & & & \\
\hline
\end{tabular}




\begin{tabular}{|c|c|c|c|c|c|c|c|c|}
\hline \multicolumn{3}{|r|}{ FUNCTION } & \multicolumn{6}{|c|}{ HAZARDOUS PROCESS CHARACTERJSTICS - PMP PLANT } \\
\hline $\mathbf{R E F}$ & $\mathbf{T}$ & DESCRIPTION & $\mathbf{k}$ & KEYWORD & MAIN VARIANCE & CONSEQUENCES & MITIGATION & Notes \\
\hline \multirow[t]{2}{*}{ 1.6.3 } & \multirow[t]{2}{*}{ c } & \multirow[t]{2}{*}{ Spill basin } & a & Flammable & Ignition & Fire, domino effects & & \\
\hline & & & b & Capacity & & & & OK \\
\hline 1.6 .4 & C & Operation manual & a & Working practice & Procedures nol followed & & & \\
\hline 120 & (3) & 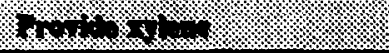 & & & & & & \\
\hline 1.8.1 & $\mathbf{M}$ & Warehouse operations & a & \multirow[t]{4}{*}{ Flammables } & Release during slorage & \multirow[t]{4}{*}{ Fire, domino effects } & $\begin{array}{l}\text { Regular inspection of } \\
\text { storage } \\
\text { Fire alarm (see 1.8.6) }\end{array}$ & \\
\hline 1.8 .2 & $\mathbf{M}$ & Lasd xylene dnum onto truck & $a$ & & Release during handling & & Handling procedures & \\
\hline 1.8 .3 & $\mathbf{M}$ & $\begin{array}{l}\text { Transport by truck to local } \\
\text { slorage }\end{array}$ & $a$ & & Release during transport & & Transportation procedures & \\
\hline 1.8 .4 & $\mathbf{M}$ & $\begin{array}{l}\text { Unload from ruck into local } \\
\text { storage }\end{array}$ & $\mathbf{a}$ & & Release during handling & & Handling procedures & $\begin{array}{l}\text { Xylene ignition } \\
\text { source }\end{array}$ \\
\hline 1.8 .5 & C & Operation manual & $a$ & Working practice & Procedures nol followed & & & \\
\hline 1.8 .6 & C & Fire alarm in central storage & 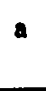 & \multirow[t]{2}{*}{ Test and mainienance } & $\begin{array}{l}\text { Malfunction of alarm } \\
\text { system }\end{array}$ & \multirow[t]{2}{*}{ Undelected fire or release } & & \multirow[t]{2}{*}{$\begin{array}{l}\text { Check maintenance } \\
\text { procedures }\end{array}$} \\
\hline 1.8 .7 & $\mathbf{C}$ & $\begin{array}{l}\text { Xylene gas delector in local } \\
\text { storage }\end{array}$ & a & & $\begin{array}{l}\text { Malfunction of gas } \\
\text { delector }\end{array}$ & & & \\
\hline 23:. & 1. & (3. & : & & & & & \\
\hline 2.1 & $\mathbf{M}$ & Add water to balch reactor & a & Pipeline, below, drum & Leakage, spill & $\begin{array}{l}\text { Release of loxic chemi- } \\
\text { cals }\end{array}$ & Swamp installed & \\
\hline 2.2 & $\mathbf{M}$ & Add MAP & 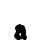 & Reaction & Wrong addition & Useless product & Sequence control & \\
\hline 2.3 & $\mathbf{M}$ & Conditioning of pH & $a$ & Reaction & Wrong pH & Useless product & Sequence control & \\
\hline 2.4 & $\mathbf{M}$ & Conditioning of temperature & $a$ & Reaction & & & & No hezards \\
\hline 31 & 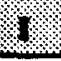 & 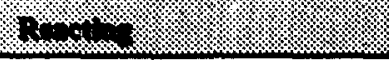 & 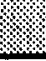 & & & & & \\
\hline 3.1 & $\mathbf{M}$ & Add MCF via feoctoystem & a & Pipeline, feedsystem & Leakage, spill & $\begin{array}{l}\text { Release of toxic chemi- } \\
\text { cals }\end{array}$ & Swamp installed & \\
\hline
\end{tabular}




\begin{tabular}{|c|c|c|c|c|c|c|c|c|}
\hline \multirow{4}{*}{ REF } & \multicolumn{2}{|r|}{ FUNCTION } & \multicolumn{6}{|c|}{ HAZARDOUS PROCESS CHARACTERISTICS - PMP PLANT } \\
\hline & $\mathbf{T}$ & DESCRITION & k & KEYWORD & MAIN VARIANCE & CONSEQUENCES & MITIGATION & Notes \\
\hline & $\mathbf{M}$ & $\begin{array}{l}\text { Reacting MAP and MCF to } \\
\text { MHPC }\end{array}$ & - & $\begin{array}{l}\text { Reaction: mildly } \\
\text { exothermic }\end{array}$ & $\begin{array}{l}\text { Failure of temperature } \\
\text { control and omission of } \\
\text { addition of ice }\end{array}$ & $\begin{array}{l}\text { Temperalure can sesch } \\
\text { boiling point }\end{array}$ & $\begin{array}{l}\text { Temperature alam at } \\
30^{\circ} \mathrm{C} \text { insualled }\end{array}$ & \\
\hline & & & b & Chemicals: MHPC & & & & MAPC nol hazardous \\
\hline 3.3 & $\mathbf{M}$ & Conditioning of $\mathrm{pH}$ & a & Reaction & See 2.3 & & & \\
\hline 3.4 & $\mathbf{M}$ & Conditioning of temperanure & $a$ & Reaction & See 3.2n & & & \\
\hline 3.5 & $\mathbf{M}$ & Add MTI via feodsystem & 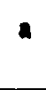 & Pipeline, feedsystem & Leakage, spill & $\begin{array}{l}\text { Relense of toxic chemi- } \\
\text { cals }\end{array}$ & Swamp installed & \\
\hline \multirow[t]{2}{*}{3.6} & \multirow[t]{2}{*}{$M$} & \multirow[t]{2}{*}{$\begin{array}{l}\text { Reacting MHPC and MTl to } \\
\text { PMP }\end{array}$} & $a$ & $\begin{array}{l}\text { Reaction: Mildly } \\
\text { exothermic }\end{array}$ & See 3.2a & & & \\
\hline & & & b & Chemicals: PMP & & & & $\begin{array}{l}\text { No hazards } \\
\text { PMP is nol classified }\end{array}$ \\
\hline 3.7 & C & $\begin{array}{l}\text { Sequence control (PMP con. } \\
\text { trol system) }\end{array}$ & $a$ & Reaction & Wrong sequence & Useless product & & \\
\hline 3.8 & c & $\begin{array}{l}\text { Process condition control } \\
\text { (PMP control system) }\end{array}$ & 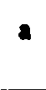 & Reaction & $\begin{array}{l}\text { Wrong process condi- } \\
\text { tions }\end{array}$ & Useless product & & \\
\hline 3.9 & C & $\begin{array}{l}\text { Process unit control (PMP } \\
\text { control sysiem) }\end{array}$ & 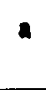 & Equipment & $\begin{array}{l}\text { Failure in process units } \\
\text { or components }\end{array}$ & $\begin{array}{l}\text { Leaks, spills, stop of } \\
\text { process }\end{array}$ & Alarm system installed & \\
\hline 3.10 & c & Operation manual & 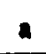 & Working practice & Procedures not followed & & & \\
\hline 10 & 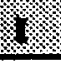 & $8 \times$ & ; & $2 \%$ & ? & ?. & & \\
\hline 4.1 & $\mathbf{M}$ & Decrease pH & 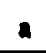 & Separation & Wrong $\mathrm{pH}$ & Bad soparation & & \\
\hline 4.2 & $\mathbf{M}$ & $\begin{array}{l}\text { Add isophoron via isophoron } \\
\text { subsystem and } \mathrm{NaCl} \text { to the } \\
\text { reactor }\end{array}$ & a & $\begin{array}{l}\text { Pipeline, isophoron } \\
\text { subsystem }\end{array}$ & $\begin{array}{l}\text { Leakage } \\
\text { Bad connection from } \\
\text { subsystem to reactor }\end{array}$ & $\begin{array}{l}\text { Release contuining water, } \\
\text { isophoron and chemicals }\end{array}$ & Swamp installed & \\
\hline 4.3 & $M$ & $\begin{array}{l}\text { Separation of waler and iso- } \\
\text { phoron phases }\end{array}$ & 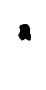 & Pipeline & Leakage & $\begin{array}{l}\text { Release contuining water, } \\
\text { isophoron and chemicals }\end{array}$ & Swamp installed & \\
\hline 4.4 & $\mathbf{M}$ & $\begin{array}{l}\text { Pump isophoron phase from } \\
\text { reactor }\end{array}$ & . & Pump & & & & \\
\hline
\end{tabular}




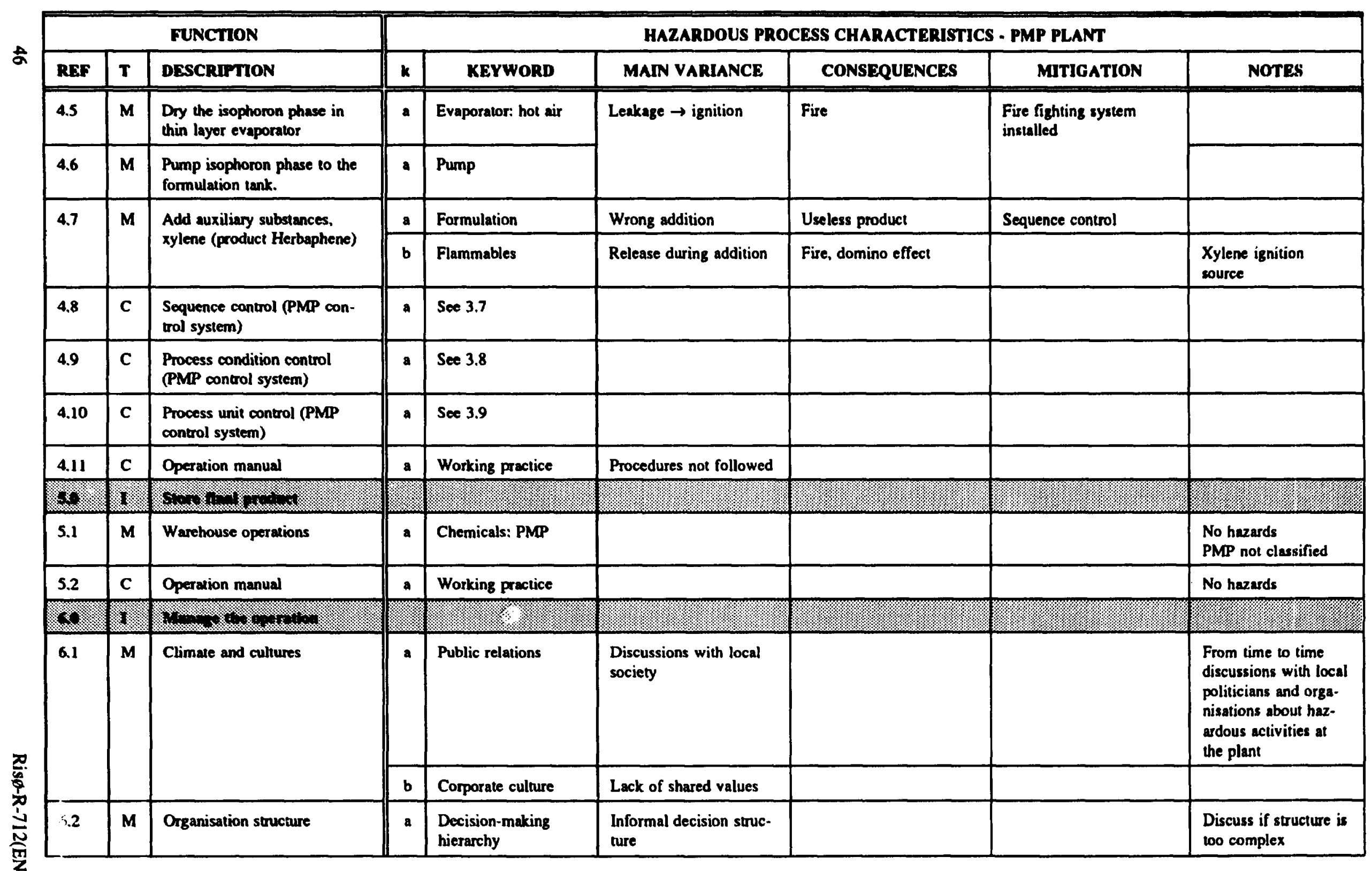




\begin{tabular}{|c|c|c|c|c|c|c|c|c|}
\hline \multicolumn{3}{|r|}{ FUNCTION } & \multicolumn{6}{|c|}{ HAZARDOUS PROCESS CHARACTERISTICS - PMP PLANT } \\
\hline $\mathbf{R E F}$ & $\mathbf{T}$ & DESCRIPTION & $\mathbf{k}$ & KEYWORD & MAIN VARIANCE & CONSEQUENCES & MITIGATION & NOTES \\
\hline \multirow[t]{2}{*}{6.3} & \multirow[t]{2}{*}{$\mathbf{M}$} & \multirow[t]{2}{*}{ Management structure } & a & Safety responsibilities & Some areas not specified & & & OK \\
\hline & & & $\mathbf{b}$ & Handling emergencies & $\begin{array}{l}\text { Deficiencies in emerg. } \\
\text { ency plan }\end{array}$ & & & OK \\
\hline 6.4 & $\mathbf{M}$ & Information & $\mathbf{a}$ & Information quality & Lack of information & & & \\
\hline 6.5 & $\mathbf{M}$ & Communications & $\mathbf{a}$ & $\begin{array}{l}\text { Incident reporting and } \\
\text { investigations }\end{array}$ & $\begin{array}{l}\text { Some relevant events } \\
\text { not included }\end{array}$ & & & No incidents reported \\
\hline 6.6 & $\mathbf{C}$ & Quality assurance system & & See 6.6.0 & & & & \\
\hline (2.1.). & 1 & 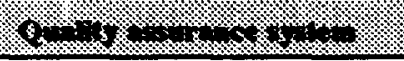 & 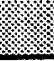 & 2: & r: & & & \\
\hline 6.6 .1 & $\mathbf{M}$ & Operation manual & $\mathbf{a}$ & Working practice & $\begin{array}{l}\text { Manuals not followed } \\
\text { and updated }\end{array}$ & & & \multirow{4}{*}{$\begin{array}{l}\text { Essential with respect } \\
\text { to handling of MCF } \\
\text { and MTI }\end{array}$} \\
\hline 6.6 .2 & $\mathbf{M}$ & Construction manual & $\mathbf{a}$ & Working practice & $\begin{array}{l}\text { Manuals not followed } \\
\text { and updated }\end{array}$ & & & \\
\hline 6.6 .3 & $\mathbf{M}$ & $\begin{array}{l}\text { Repair and maintenance man- } \\
\text { ual }\end{array}$ & $\mathbf{a}$ & Working practice & $\begin{array}{l}\text { Manuals not followed } \\
\text { and updated }\end{array}$ & & & \\
\hline 6.6 .4 & $\mathbf{M}$ & Emergency plan & $\mathbf{a}$ & $\begin{array}{l}\text { Emergency exercises } \\
\text { and training }\end{array}$ & $\begin{array}{l}\text { Personnel not capable in } \\
\text { case of an emergency }\end{array}$ & & & \\
\hline 8 & $\sqrt{3}$ & 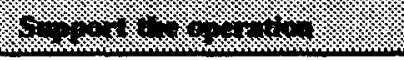 & & 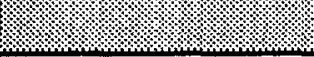 & & & & \\
\hline 7.1 & $\mathbf{M}$ & PMP control system & & See 7.1.0 & & & & \\
\hline 7.2 & $\mathbf{M}$ & Clean plant area & $\mathbf{a}$ & Orderly, tidy & Disorder & & & \\
\hline 7.3 & $\mathbf{M}$ & Clean process equipment & & See 7.3.0 & & & & \\
\hline 7.4 & $\mathbf{M}$ & Emergency system & & See 7.4.0 & & & & \\
\hline 7.5 & $\mathbf{M}$ & Waste disposal & & See 7.5.0 & & & & \\
\hline 7.6 & $\mathbf{M}$ & Training of personnel & & $\begin{array}{l}\text { Qualifications and } \\
\text { education }\end{array}$ & Personnel not qualified & & & \\
\hline 7.7 & c & Quality assurance system & & See 6.6.0 & & & & \\
\hline 818. & 1. & 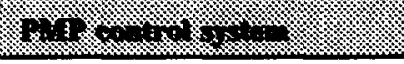 & & & & & & \\
\hline 7.1 .1 & $\mathbf{M}$ & Sequence control & 8 & Reaction & Wrong sequence & Useless product & & \\
\hline
\end{tabular}




\begin{tabular}{|c|c|c|c|c|c|c|c|c|}
\hline \multicolumn{3}{|r|}{ FUNCTION } & \multicolumn{6}{|c|}{ HAZARDOUS PROCESS CHARACTERISTICS - PMP PLANT } \\
\hline REF & $\mathbf{T}$ & DESCRIPTION & k & KEYWORD & MAIN VARIANCE & CONSEQUENCES & MITIGATION & NOTES \\
\hline \multirow[t]{2}{*}{7.1 .2} & \multirow[t]{2}{*}{$\mathbf{M}$} & \multirow[t]{2}{*}{ Process condition control } & a & Temperature & Wrong temperature & $\begin{array}{l}\text { Temperature can reach } \\
\text { boiling point }\end{array}$ & $\begin{array}{l}\text { Temperature alam at } \\
30^{\circ} \mathrm{C} \text { installed }\end{array}$ & \\
\hline & & & b & pH & Wrong pH & Useless product & & \\
\hline 7.1 .3 & $\mathbf{M}$ & Process unit control & a & Equipment & $\begin{array}{l}\text { Failure in process units } \\
\text { or components }\end{array}$ & $\begin{array}{l}\text { Leaks, spills, stop of } \\
\text { process }\end{array}$ & Alarm system installed & \\
\hline 7.1 .4 & $\mathbf{M}$ & Fire alarm system & $\mathbf{a}$ & Test and maintenance & $\begin{array}{l}\text { Malfunction of fire } \\
\text { alarm syslem }\end{array}$ & Undelected fire & & $\begin{array}{l}\text { Check maintenance } \\
\text { procedures }\end{array}$ \\
\hline 7.1.5 & $\mathbf{M}$ & Gas alarm system & $\mathbf{a}$ & Test and maintenance & $\begin{array}{l}\text { Malfunction of gas } \\
\text { alarm system }\end{array}$ & Undelected release of gas & & $\begin{array}{l}\text { Check maintenance } \\
\text { procedures }\end{array}$ \\
\hline 7.1 .6 & $\mathrm{c}$ & QA-system & & See 6.6.0 & & & & \\
\hline \multirow[t]{2}{*}{7.1 .7} & \multirow[t]{2}{*}{ C } & \multirow[t]{2}{*}{$\begin{array}{l}\text { Sel-points, alarm levels, pass- } \\
\text { words etc.) }\end{array}$} & $\mathbf{a}$ & Equipment & $\begin{array}{l}\text { Malfunction of alarms } \\
\text { and controls }\end{array}$ & $\begin{array}{l}\text { Critical conditions not } \\
\text { detected }\end{array}$ & & $\begin{array}{l}\text { Check maintenance } \\
\text { procedures }\end{array}$ \\
\hline & & & b & Software & Soltware errors & & & To be investigated \\
\hline 930 & 18 & 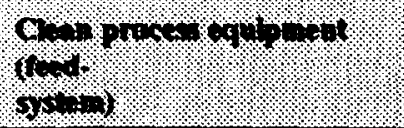 & & & & & & \\
\hline 7.3.1 & $\mathbf{M}$ & Remove all drums & $a$ & $\begin{array}{l}\text { Health hazard: Che- } \\
\text { mical contact }\end{array}$ & $\begin{array}{l}\text { Chemical protective } \\
\text { clothing in bad condi- } \\
\text { tions or not used }\end{array}$ & $\begin{array}{l}\text { Chemical exposure (small } \\
\text { amounts released) }\end{array}$ & & \\
\hline \multirow[t]{2}{*}{7.3 .2} & \multirow[t]{2}{*}{$\mathbf{M}$} & \multirow[t]{2}{*}{$\begin{array}{l}\text { Purification and drainage of } \\
\text { feedsystem }\end{array}$} & a & $\begin{array}{l}\text { Health hazard: Che- } \\
\text { mical contact }\end{array}$ & $\begin{array}{l}\text { Cleaning operations not } \\
\text { performed properly }\end{array}$ & $\begin{array}{l}\text { Chemical exposure (small } \\
\text { amounts released) }\end{array}$ & & \\
\hline & & & $\mathbf{b}$ & $\begin{array}{l}\text { Supervision and sup- } \\
\text { port }\end{array}$ & Not performed properly & & & \\
\hline 7.3 .3 & $M$ & Take down of feedsystem & $\mathbf{a}$ & $\begin{array}{l}\text { Health hazard: Che- } \\
\text { mical contact }\end{array}$ & & & & $\begin{array}{l}\text { Low hazard, small } \\
\text { amounts of chemicals }\end{array}$ \\
\hline 7.3 .4 & $\mathbf{M}$ & Cleaning of components & a & $\begin{array}{l}\text { Health hazard: Che- } \\
\text { mical contact }\end{array}$ & & & & $\begin{array}{l}\text { Low hazard. small } \\
\text { amounts of chemicals }\end{array}$ \\
\hline 7.3 .5 & C & Chemical protective clothing & a & Health hazand & $\begin{array}{l}\text { Chemical protective } \\
\text { clothing in bad condi- } \\
\text { tions or not available }\end{array}$ & $\begin{array}{l}\text { Chemical exposure (small } \\
\text { amounts released) }\end{array}$ & & \\
\hline
\end{tabular}




\begin{tabular}{|c|c|c|c|c|c|c|c|c|}
\hline \multicolumn{3}{|r|}{ FUNCTION } & \multicolumn{6}{|c|}{ HAZARDOUS PROCESS CHARACTERISTICS - PMP PLANT } \\
\hline REF & $\mathbf{T}$ & DESCRIPTION & $\mathbf{k}$ & KEYWORD & MAIN VARIANCE & CONSEQUENCES & MITIGATION & Notes \\
\hline 7.3.6 & $\mathbf{c}$ & Inspection & $\mathbf{a}$ & $\begin{array}{l}\text { Supervision and sup- } \\
\text { port }\end{array}$ & Not performed properly & & & \\
\hline 7.3.7 & c & $\begin{array}{l}\text { Operation and maintenance } \\
\text { manuals }\end{array}$ & $\mathbf{a}$ & Working practice & Manuals not followed & & & \\
\hline (18. & . & 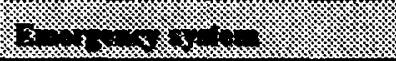 & & & & & & \\
\hline 7.4.1 & $\mathbf{M}$ & PMP unit alarms & a & Test and maintenance & Malfunction of alarms & Release/fire not detected & & Check lest procedures \\
\hline \multirow[t]{2}{*}{ 7.4.2 } & \multirow[t]{2}{*}{$\mathbf{M}$} & \multirow{2}{*}{$\begin{array}{l}\text { General emergency system at } \\
\text { the enterprise (local, internal } \\
\text { and external) }\end{array}$} & a & Test and maintenance & Malfunction of alarms & & & To be investigated \\
\hline & & & $\mathbf{b}$ & $\begin{array}{l}\text { Emergency communi- } \\
\text { cation }\end{array}$ & & & & \\
\hline 7.43 & C & Gas alarm system & $\mathbf{a}$ & Test and maintenance & $\begin{array}{l}\text { Malfunction of gas } \\
\text { alarms }\end{array}$ & $\begin{array}{l}\text { Release of gas not } \\
\text { detected }\end{array}$ & & Check test procedures \\
\hline 7.4.4 & $\mathbf{C}$ & Fire alarm system & $\mathbf{a}$ & Test and maintenance & & Fire not detected & & Check test procedures \\
\hline 7.4.5 & C & Emergency plan & & See 6.6.4 & & & & \\
\hline 80 & . & 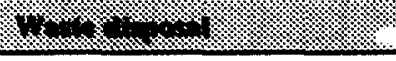 & & : & & & & \\
\hline 7.5.1 & $\mathbf{M}$ & $\begin{array}{l}\text { Collect solid waste, empty } \\
\text { drums (MAP, MCF, MTI. } \\
\text { xylene etc.) }\end{array}$ & a & Health hazards & $\begin{array}{l}\text { Drums not handled } \\
\text { properly }\end{array}$ & Exposure & & \\
\hline 7.5.2 & $\mathbf{M}$ & Destruction of chemicals & $\mathbf{a}$ & Health hazards & $\begin{array}{l}\text { Drums and destruction } \\
\text { chemicals not handled } \\
\text { properly }\end{array}$ & Exposure & & \\
\hline 7.5.3 & $\mathbf{M}$ & $\begin{array}{l}\text { Collection of waste water } \\
\text { (from separation, see } 4.3 \text { ) }\end{array}$ & $\mathbf{a}$ & Equipment & Leakage, spills & $\begin{array}{l}\text { Release to sewer or } \\
\text { swamp of water contain- } \\
\text { ing chemicals }\end{array}$ & & $\begin{array}{l}\text { To local waste water } \\
\text { trealment plant, prob- } \\
\text { lem? }\end{array}$ \\
\hline 7.5.4 & $\mathbf{M}$ & $\begin{array}{l}\text { Exhaussed air from PMP pro- } \\
\text { duction building }\end{array}$ & $\mathbf{a}$ & Equipment: pipeline & Leaks & $\begin{array}{l}\text { Release of air containing } \\
\text { small amounts of chemi- } \\
\text { cals }\end{array}$ & & \\
\hline 7.5.5 & $M$ & $\begin{array}{l}\text { Ventilation system, combus- } \\
\text { tion (powes plant or smoke- } \\
\text { stack) }\end{array}$ & $\mathbf{a}$ & Equipment & $\begin{array}{l}\text { Flammable gases not } \\
\text { detected }\end{array}$ & Explosion? & & To be investigated \\
\hline 7.5 .6 & C & QA-system & & $S e c 6.6 .0$ & & & & \\
\hline
\end{tabular}




\begin{tabular}{|c|c|c|c|c|c|c|c|c|}
\hline \multicolumn{3}{|r|}{ FUNCTION } & \multicolumn{6}{|c|}{ HAZARDOUS PROCESS CHARACTERISTICS - PMP PLANT } \\
\hline $\mathbf{R E F}$ & $\mathbf{T}$ & DESCRIPTION & $k$ & KEYWORD & MAIN VARIANCE & CONSEQUENCES & MITIGATION & NOTES \\
\hline 7.5.7 & C & $\begin{array}{l}\text { Gas delector in ventilation } \\
\text { system }\end{array}$ & $\mathbf{a}$ & Test and maintenance & $\begin{array}{l}\text { Malfunction of gas } \\
\text { delector }\end{array}$ & Explosion? & & To be investigaled \\
\hline 7.5.8 & C & Control and supervision & $\mathbf{a}$ & Communication & $\begin{array}{l}\text { Boiler lender not con- } \\
\text { tacled before stan of } \\
\text { production }\end{array}$ & & & \\
\hline 20 & : & 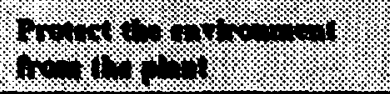 & & & & & & \\
\hline \multirow[t]{2}{*}{8.1} & \multirow[t]{2}{*}{$M$} & \multirow[t]{2}{*}{ Contain process nuids } & \multirow[t]{2}{*}{ a } & \multirow[t]{2}{*}{ Equipment } & \multirow{2}{*}{$\begin{array}{l}\text { Overfilling } \\
\text { Pipe leakage }\end{array}$} & Release to drain/sewer & & \\
\hline & & & & & & Release to soa & & Very unlikely \\
\hline \multirow[t]{2}{*}{8.2} & \multirow[t]{2}{*}{$\mathbf{M}$} & \multirow[t]{2}{*}{ Avoid accidental releases } & a & Equipment & $\begin{array}{l}\text { Malfunction of scrubber } \\
\text { system }\end{array}$ & $\begin{array}{l}\text { Toxic release (small } \\
\text { amounts of chemicals) }\end{array}$ & & \\
\hline & & & $b$ & Equipment & $\begin{array}{l}\text { Malfunction of ventila- } \\
\text { tion system }\end{array}$ & $\begin{array}{l}\text { Toxic release (small } \\
\text { amounts of chemicals) }\end{array}$ & & \\
\hline 8.3 & $\mathbf{M}$ & Control waste disposal & & See 8.1 and 8.2 & & & & \\
\hline (1) & 1 & 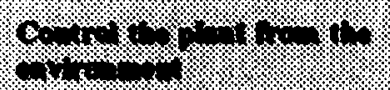 & & & & & & \\
\hline \multirow[t]{2}{*}{9.1} & \multirow[t]{2}{*}{$\mathbf{M}$} & \multirow{2}{*}{$\begin{array}{l}\text { Protect against natural disas. } \\
\text { ters }\end{array}$} & $a$ & Earthquake & & & & No hazards \\
\hline & & & b & Flood & & & & No hezards \\
\hline
\end{tabular}


Procodures for MTI hasding

QA-sysiom

Operation mamual

Selfory officer
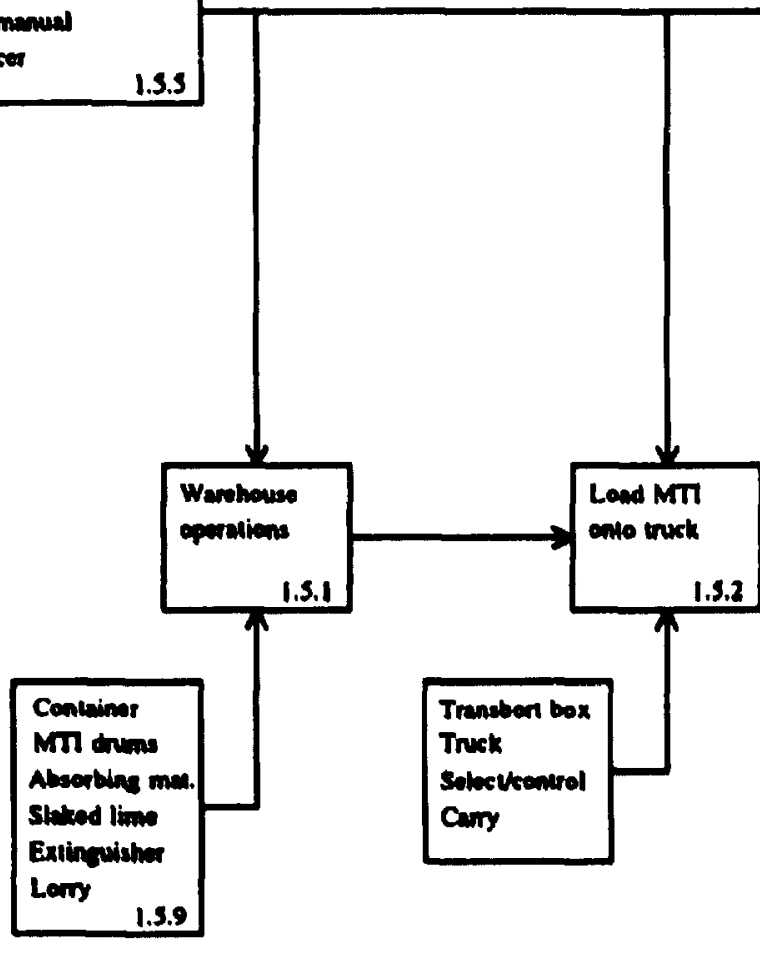

Tranclien box

Truct

solockvenemel

Cany

\section{Provide MTI (1.5.0)}



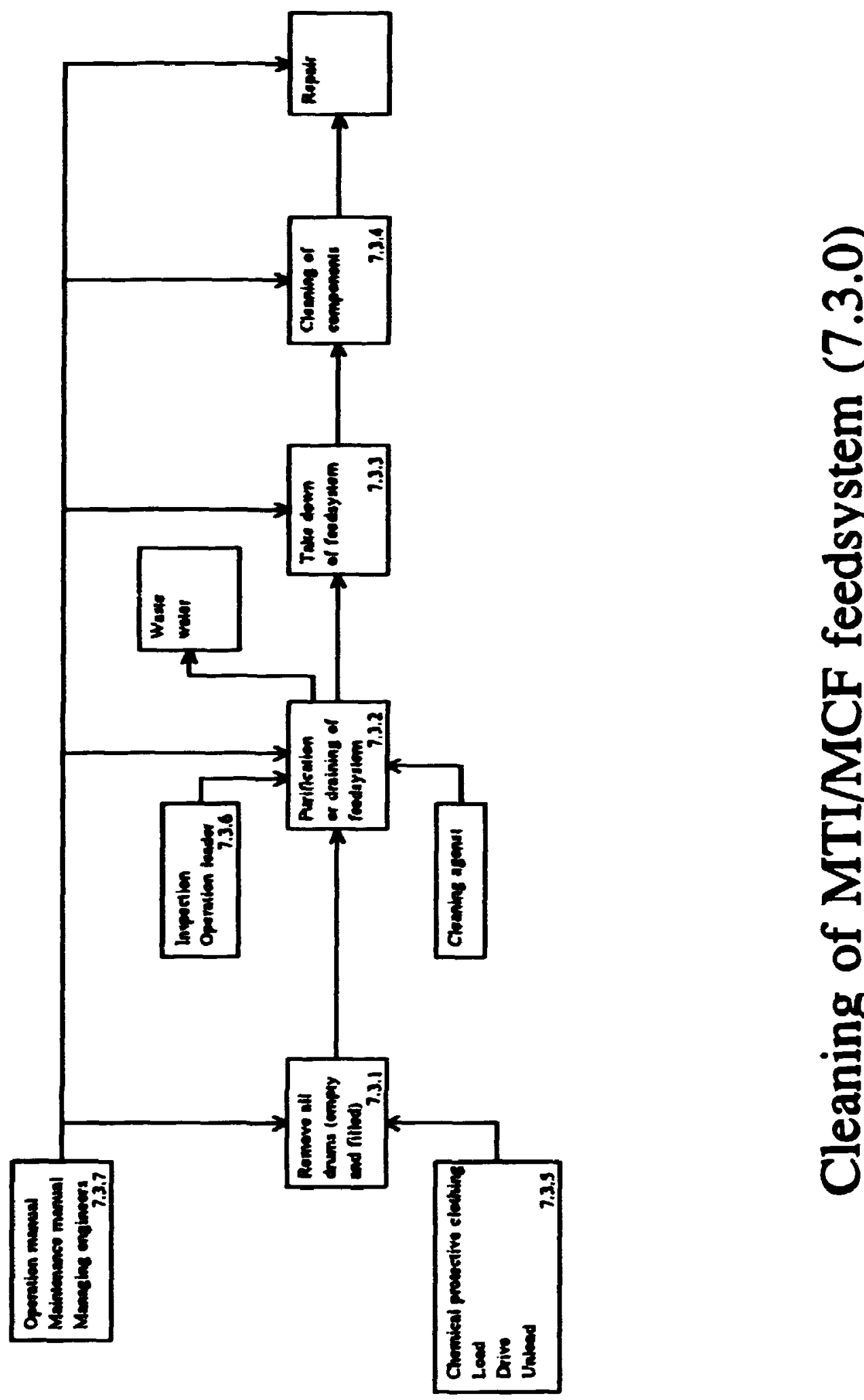

8
0
0
0
0

$\sum_{1}^{1}$

$\frac{0}{0}$ 


\section{B Case study of a section of a continuous process plant}

\section{B.I Introduction}

The sectiva of pland chasen for study is a methonaer and compressor. shown in Figure B1. This exanpic has beea exleasively stodied and reported upon elsewhere (Anon. 1993. Welts et at. 1993) and ody a bief descripion is given here. in B.2 betow. The main conchaions and recomenendions from this exanple are sismarized i chaper 5 of the main repont bogther with the comesponding results from the beich reactor example.

\section{B.2 A brief plant section description}

The plan section is shown in Figure Bl. A misture of bydrogen and methase gas. containing oxides of carton as $\mathrm{CO}$ and $\mathrm{CO}$, eners from the upstrean absorber D1004. The mixhure posses throngh heat exchonger E-101. where it is heated before passing over a plationea catalyst in reactor R-101.

In R-101. oxides of carbon react with hydrogen and are converted to muthane and water. litheratiof considerable heat: the reaction is unstable. The gas exits the reactor and is croled in E-101 by exctanging beal with the incoming gas stream. Because the reaction is exothermic and wastrble, a uip system is provided which. when uriggered bypasses the flow of ges around the reactor.

The gas is further cooled in beat exchanger E-102 and then passes to a brockout poe. D-102. where entrained water is removed by gravity. Waste water from D-102, which contains dissolved bydrogen and methane and some dissolved salis from the upstream process. is released to the sewer drains by a level controller which maintains a water seal.

Downstrean of D-102, some of the gas is bled of as fuel and a relief valve is provided to cope with overpressure conditions. The remaining gas is compressed in a reciprocating compressor and passes to the downstream process. The compressom is provided with its own trip sysiem. which operales upon either low lubricating oil in the compressor or upon high water level in D-102. In the event of a compressox trip. the relief valve. RVI, is expecied to lift.

It most he meed that the P\&l diagram, while hesed upon a real plane, is inlended in the a preliminary diarrem, io the used as an underereduale and postgredure exercise in harend identification. It is therefore aclonowled sed that Figure Bl, as drawn, conteins many onissions and is not intended to be representalive of gand prectice.

\section{B.3 Plant section functional model}

The plant-section functional mndel was developed according to the methods described in the text. starting with the intent of the plant as: From a hydroken \& merhane gas mircure wilh $\mathrm{CO} / \mathrm{CO}_{2}$ contert of nominally $2 \%$ (max $10 \%$ ) and at a pressure of 20har. produre a gas mixture with $\mathrm{CO} \mathrm{CO}_{2}$ rontent $\leq 10 \mathrm{ppm}$ and at a pressure of thlaw.

The model was produced on the assumption that the plant-section was not yet fully designed and that less information was availahte than is actually given in the 
P\&I diagram of Figure BI. Since the section falls roughly into two stages: Methanation and Compression, these were chosen as the two initial Methods. Altematively, three Methods could have been chosen: Methanation; Water removal; and Compression.

To these two Methods, two more standard Methods were added: Support the operation and Manage the operation, and two standard Constraints: Protect the plant from the environment and Protect the environment from the plant.

The model was then expanded, item by item, to a level that was felt to be reasonable for an early stage of plant design. Note that, though it appears as Method 4, Manage the operation has not been expanded; this decision was made for two reasons: Firstly, this is a section of a plant and no information is available as to the overall management structure. Certainly, one could have been created but it was felt that this would be a rather artificial exercise. Secondly, the example in Appendix A treats this aspect at some length and, since it was difficult to imagine that the management of a continuous plant would be radically different from one devoted to batch processes, an elaborate treatment of management would be repetitious.

It has already been remarked (paragraph 5.3, above) that substantial repetition of the same hazards occurs during this kind of analysis; it is interesting to note that there is evidence for this in the construction of the model, even before hazard identification has begun. For example, Method 3, Support the operation, includes the sub-Method 3.6, Security, as part of the suggested standard expansion; however, Constraint 6, Protect plant from the environment, contains the sub-Method 6.4, Protect against unauthorised access to plant. Clearly these requirements overlap and it is probable that other areas of overlap could be identified. While the natural tendency is to eliminate such duplication, it is felt that things should be left as they are for the moment until more experience has been gained. Clearly, however, the existence of such duplicates offers a useful cross-check against accidentally omitting a function. Note that in the subsequent analysis, the sub-Method 3.6, Security, has not been developed because the necessary information occurs lower down at sub-Method 6.4, Protect against unauthorised access to plant; this was done merely to save space.

\section{B.4 Hazard analysis of the functional model}

As recommended in the description of the method (paragraph 4, above) the CHA process of hazard identification was applied botom-up; i.e. starting, literally, at Intent $\mathbf{1 2 . 0}$ on the analysis form. Keywords were taken from the list given in an earlier report [Anon., 1993], supplemented by the keywords NOT, for every stage of the model, and TOO MUCH, and TOO LITTLE where this was felt to be appropriate. The following discussion follows the bottom-up approach of the original analysis; only points of interest are elaborated in detail.

Functions 9.0, 10.0,11.0, and 12.0: these have not been developed. The flowsheet does not have sufficient information to analyse these functions for hazards; consequently they have been left with the note: Process engineering to advise.

Function 8.0: has been given the keyword NOT. It is known that the purpose of this section of the plant is to remove the oxides of cirbon which will cause problems for the downstream plant. The rest of the analysis follows from this premise.

Function 7.0: an increase in oxide level leads to an increase in the exothermic reaction in R-101; clearly such a condition is hazardous and slould be alarmed and integrated with the existing metiaaistor trip.

Function 6.4: This shows the utility of the keywords and of the proposed standard Methods. It is interesting to n.t that. as well as the obvious problems of 
sabotage and theft, the method reveals the possibility of 'well-intentioned' intruders, such as the media and family members, gaining access to the site during emergencies and interfering with the activities of the emergency services.

Function 6.3: has four occurrences of the keyword EXTREME_WEATHER and required the analyst's imagination to apply this keyword in such a way as to obtain useful results; suggesting that this keyword would benefit from sub-categories.

Functions 6.2 and 6.1: these two standard Methods appear to be complementary; it may he necessary to revise them or make a very precise distinction between a 'man-made disaster' and an 'incident in adjacent plant'. At present, the only difference seems to be one of scale.

Function 6.0: as an Intent, anything recorded here would merely repeat the results of the lower-level expansions and so it has been left blank.

Function 5.3: it is evident that the keyword TOXICITY ought to be applied to the disposal of effluent; however, the P\&I diagram has no information on the toxicity or otherwise of spent platinum catalyst. In practice, this would have been resolved in the Substances List, before the analysis was begun but constraints of time and space have precluded this. However, it does underline the necessity for a complete substance list to be prepared before the analysis is undertaken and raises the question of the scope of such a list: some substances may need to be listed in 'before and after' states.

Functions 3.1.7 and 3.1.8: each of these functions refers to maintenance of a trip system, which, since it operates on demand, must be tested at frequent intervals. At this level of decomposition, none of the existing keywords would lead to a consideration of such test problems. However, further decomposition would (should) introduce trip system testing as a sub-Method; in which case, keywords such as NOT and TOO MUCH would reveal the potential problem.

Again, some modification to the keyword list seems to be indicated. In the example, the keyword TEST was used, though this may not be generally applicable and may be too specific to these circumstances. The question to be resolved is, bearing in mind that TOMHID is a high-level analysis method: do we expect the keyword list to lead to problems at this level of detail or not?

Function 3.1.5 and 3.1.4: again, a new keyword has been introduced.

Functions $3.1 .3,-.2,-.1$, and -.0 : here, by way of illustration, the opposite procedure has been adopted to that used in Function 6.0. Because analysis suggests that, at this level of detail, Functions 3.1.1, 3.1.2, and 3.1.3 all share common hazards, which they also share with 3.1.4 through 3.1.8, it makes sense to consolidate these hazards into a single set of statements under the Intent, Function 3.1.0.

This highlights one aspect of a problem already identified in previous analyses: the repetitive nature of many of the hazards found by this method. In this case, the hazards are not repetitive across different functions (E.g. as between Functions 3.6 and 6.4) but within a Function. One way to resolve this aspect of the problem (already proposed in WP4, software specification) is by the use of a hazard library which, by stating hazards in a standard form would allow duplicates to be readily identified by the software. That done, the user can take appropriate action: where duplicates occur within a function, they can be collected and moved up to the function's Intent; where duplicates occur across functions, they can be tied to the most appropriate place and then cross-referenced at the other places where they occur.

This leads naturally to the concept of a Specific Hazard Dictionary, a data-base which, analogously to a data dictionary in software engineering, would list the identified hazards against where they occur in the analysis.

Function 3.7: while it is known that start-up, and the presence of process lines which are used only for that purpose, constitute a source of hazards for this sys- 
tem it was felt that the P\&I diagram, as at present given, offers no information to allow this aspect of operation to be analysed. Consequently, it has been left unresolved.

Function 3.6: as already noted, this duplicates Function 6.4 and requires no further analysis.

Function 3.4: has not been developed because no information yet exists as to an emergency plan for the plant.

Function 3.3: has not been developed because the system is not under centralised control and the trip systems themselves are treated throughout the analysis.

Function 1.2.0 and its expansions: these clearly form a duplicate of the analysis under Constraint 2.2 and so have been referenced to it, illustrating the scheme proposed above.

Functions 6 and 5: here, the hazards identified by the sub-functions have been collected and listed under each parent functions 'Consequences'. Certainly, doing so offers a person reading the analysis the opportunity to view the hazards without having to read further and as such this approach may be advantageous. However, to do so in every case would clearly result in an enormous amount of duplicated information. It seems possible that the Specific Hazard Dictionary, proposed above under Functions 3.1.5 and 3.1.4, might be a better solution to the problem. 
总

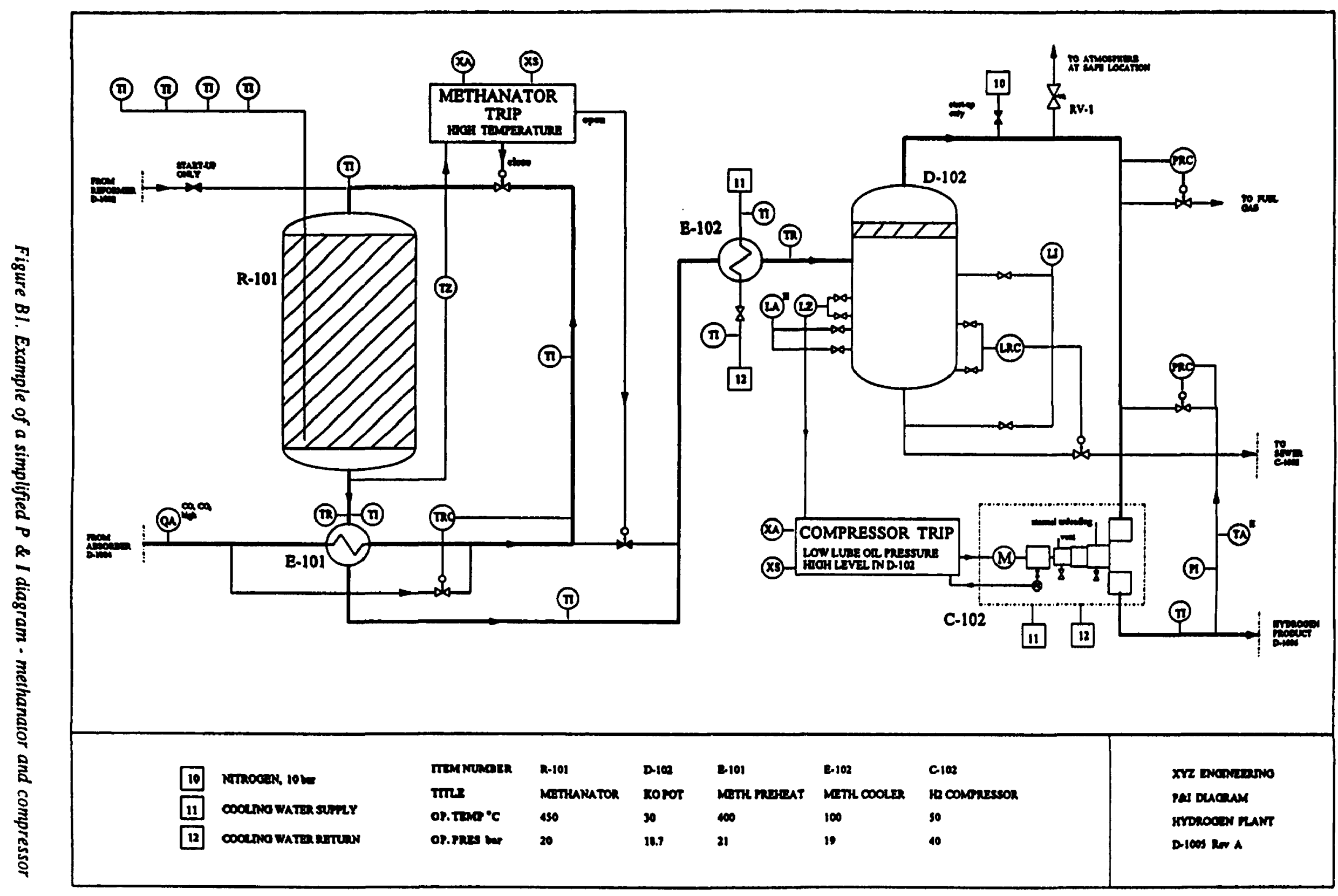




\begin{tabular}{|c|c|c|c|c|c|c|c|c|}
\hline \multicolumn{3}{|c|}{ FUNCTION } & \multicolumn{6}{|c|}{ HAZARD IDENTIFICATION } \\
\hline Ref & $\mathbf{T}$ & Description & $\mathbf{k}$ & Keyword & Main variance & Consequences & Mitigation & Notes \\
\hline 0 & 1 & $\begin{array}{l}\text { From a hydrogen \& } \\
\text { methane gas mixture } \\
\text { with } \mathrm{CO} / \mathrm{CO}_{2} \text { content } \\
\text { of nominally } 2 \% \text { (max } \\
10 \% \text { ) and at a pressure } \\
\text { of } 20 \mathrm{bar} \text {, produce a } \\
\text { gas mixture with } \\
\mathrm{CO} / \mathrm{CO}_{2} \text { content s } \\
10 \mathrm{ppm} \text { and a a } \\
\text { pressure of } 40 \mathrm{bar} \text {. }\end{array}$ & & & & & & \\
\hline 1 & $\mathbf{M}$ & Remove $\mathrm{CO} / \mathrm{CO}_{2}$ & & & & & & \\
\hline 2 & $\mathbf{M}$ & Compress gas to $40 \mathrm{bar}$ & & & & & & \\
\hline 3 & $\mathbf{M}$ & Suppont operation & & & & & & \\
\hline 4 & $\mathbf{M}$ & Manage the operation & & & & & & \\
\hline 5 & C & $\begin{array}{l}\text { Protect environment } \\
\text { from plant. }\end{array}$ & & See 5.1-5.4 & See 5.1-5.4 & $\begin{array}{l}\text { Possible fire and } \\
\text { explosion through loss } \\
\text { of containment. } \\
\text { Excess flaring will cause } \\
\text { unnecessary loss of } \\
\text { energy, bright lights at } \\
\text { night, etc. } \\
\text { Risks in disposal of } \\
\text { used catalyst. } \\
\text { Risk of explosion from } \\
\text { hydrogen and/or } \\
\text { methane in the sewers. } \\
\text { Noise, giving risk of } \\
\text { disturbance to local } \\
\text { population and long- } \\
\text { term hearing damage to } \\
\text { plant personnel. }\end{array}$ & See 5.1.5.4 & See 5.1.5.4 \\
\hline
\end{tabular}




\begin{tabular}{|c|c|c|c|c|c|c|c|c|}
\hline \multicolumn{3}{|c|}{ FUNCTION } & \multicolumn{6}{|c|}{ HAZARD IDENTIFICATION } \\
\hline Ref & $\mathbf{T}$ & Description & k & Keyword & Main variance & Consequences & Mittgation & Notes \\
\hline 6 & $\mathbf{c}$ & $\begin{array}{l}\text { Protect plant from } \\
\text { environment }\end{array}$ & & See $6.1 \cdot 6.4$ & See 6.1-6.4 & $\begin{array}{l}\text { Impact from vehicles. } \\
\text { leading to a release of } \\
\text { flammables. } \\
\text { External threats from } \\
\text { explosion, fire, toxic } \\
\text { release, and contami- } \\
\text { nating material. } \\
\text { Environmental threats } \\
\text { from high winds, } \\
\text { freezing of entrapped } \\
\text { water, brittle fracture of } \\
\text { metals, etc. } \\
\text { Plant at risk from } \\
\text { deliberate or accidental } \\
\text { intruders. } \\
\text { Catalyst is valuable and } \\
\text { theft of catalyst is } \\
\text { possible during } \\
\text { (un)loading operations } \\
\text { or when calalyst is } \\
\text { stored at site which may } \\
\text { encourage intruders. }\end{array}$ & See 6.1.6.4 & See 6.1.6.4 \\
\hline 7 & C & $\begin{array}{l}\text { Inlet } \mathrm{CO} / \mathrm{CO}_{2} \text { content } \\
\leq 10 \%\end{array}$ & & & & & & \\
\hline 8 & C & $\begin{array}{l}\text { Outlet } \mathrm{CO} / \mathrm{CO}_{2} \text { content } \\
510 \mathrm{ppm}\end{array}$ & & & & & & \\
\hline 9 & C & Inlet pressure $20 \mathrm{bar}$ & & & & & & \\
\hline
\end{tabular}




\begin{tabular}{|c|c|c|c|c|c|c|c|c|}
\hline \multicolumn{3}{|c|}{ FUNCTION } & \multicolumn{6}{|c|}{ HAZARD IDENTIFICATION } \\
\hline Ref & $\mathbf{T}$ & Description & $\mathbf{k}$ & Keyword & Maln varlance & Consequences & Mitigation & Notes \\
\hline 10 & $\mathbf{C}$ & Outlet pressure 40 bar & & & & & & \\
\hline 11 & C & Inlet lemperature ibd & & & & & & \\
\hline 12 & C & Outlet temperature tbd & & & & & & \\
\hline 1.0 & 1 & Remove $\mathrm{CO} / \mathrm{CO}_{2}$ & & & & & & \\
\hline 1.1 & $\mathbf{M}$ & $\begin{array}{l}\text { Conversion of } \mathrm{CO} / \mathrm{CO}_{2} \\
\text { to methane and water } \\
\text { by catalytic reaction. }\end{array}$ & & See 1.1 .0 & See 1.1 .0 & See 1.1 .0 & See 1.1 .0 & See 1.1 .0 \\
\hline 1.2 & $\mathbf{M}$ & $\begin{array}{l}\text { Remove liquid warer } \\
\text { (as entrained droplets) }\end{array}$ & & See 1.2.0 & See 1.2 .0 & See 1.2 .0 & See 1.2 .0 & See 1.2 .0 \\
\hline 1.1 .0 & 1 & $\begin{array}{l}\text { Conven } \mathrm{CO} / \mathrm{CO}_{2} \text { to } \\
\text { methane and water by } \\
\text { catalytic reaction }\end{array}$ & & & & & & \\
\hline 1.1.1 & $\mathbf{M}$ & $\begin{array}{l}\text { Heat inlet stream by } \\
\text { heal-exchanger E-101 }\end{array}$ & & See 1.1.3 & See 1.1 .3 & See 1.1.3 & See 1.1 .3 & See 1.1 .3 \\
\hline 1.1 .2 & $\mathbf{M}$ & $\begin{array}{l}\text { React over catalyst in } \\
\text { reactor } R-101\end{array}$ & $\begin{array}{l}\mathbf{a} \\
\mathbf{b}\end{array}$ & $\begin{array}{l}\text { NOT } \\
\text { TOO MUCH }\end{array}$ & $\begin{array}{l}\text { No reaction. } \\
\text { Runaway reaction. }\end{array}$ & $\begin{array}{l}\text { See } 8.0 \\
\text { See 1.1.4 }\end{array}$ & $\begin{array}{l}\text { See } 8.0 \\
\text { See 1.1.4 }\end{array}$ & $\begin{array}{l}\text { See } 8.0 \\
\text { See 1.1.4 }\end{array}$ \\
\hline 1.1 .3 & $\mathbf{M}$ & $\begin{array}{l}\text { Cool outlet stream by } \\
\text { heat-exchanger } \\
\text { E-101 }\end{array}$ & a & $\begin{array}{l}\text { NOT } \\
\text { NOT }\end{array}$ & $\begin{array}{l}\text { Overheated gas, exit R- } \\
101 \\
\text { Under heated gas, inlet } \\
\text { R-101 }\end{array}$ & $\begin{array}{l}\text { Extra duty required of } \\
\text { E-102 and D-102. } \\
\text { Reaction in R-101 may } \\
\text { not take place or } \\
\text { proceed to completion. } \\
\text { leading to off-spec } \\
\text { product to down-stream } \\
\text { plant. See } 8.0\end{array}$ & & $\begin{array}{l}\text { Process engincering to } \\
\text { advise. }\end{array}$ \\
\hline
\end{tabular}




\begin{tabular}{|c|c|c|c|c|c|c|c|c|}
\hline \multicolumn{3}{|c|}{ FUNCTION } & \multicolumn{6}{|c|}{ HAZARD IDENTIFICATION } \\
\hline Ref & $\mathbf{T}$ & Description & $\mathbf{k}$ & Keyword & Main variance & Consequences & Mitigation & Notes \\
\hline 1.1 .4 & $\mathbf{C}$ & $\begin{array}{l}\text { Prevent runaway of } \\
\text { exothermic reaction in } \\
\text { R-101 }\end{array}$ & $\mathbf{a}$ & NOT & $\begin{array}{l}\text { Runaway exothermic } \\
\text { reaction in } R-101 \text {. }\end{array}$ & $\begin{array}{l}\text { Catastrophic failure of } \\
\text { reactor vessel, leading to } \\
\text { release of flammables } \\
\text { and probable explosion. }\end{array}$ & Methanator trip system. & $\begin{array}{l}\text { Evidence suggests that } \\
\text { monitoring the reactor } \\
\text { outlet temperature will } \\
\text { not provide a rapid } \\
\text { enough response for a } \\
\text { trip, nor will it detect } \\
\text { hot-spots in the } \\
\text { catalyst beds. Suggest } \\
\text { trip system is revised } \\
\text { to measure individual } \\
\text { bed temps. }\end{array}$ \\
\hline 1.2 .0 & $\mathbf{I}$ & Remove water & & & & & & \\
\hline 1.2 .1 & $\mathbf{M}$ & $\begin{array}{l}\text { Cool inlet stream by } \\
\text { heat exchanger E-102 }\end{array}$ & $\mathbf{a}$ & NOT & See 2.2.a & See 2.2.a & See 2.2.a & See 2.2.a \\
\hline 1.2 .2 & $\mathbf{M}$ & $\begin{array}{l}\text { Separate water from } \\
\text { gas by gravity in KO- } \\
\text { pot D-102 }\end{array}$ & $\mathbf{a}$ & NOT & See 2.2.a & See 2.2.a & See 2.2.a & See 2.2.a \\
\hline 1.2 .3 & $\mathbf{M}$ & $\begin{array}{l}\text { Discharge water to } \\
\text { sewer }\end{array}$ & $\begin{array}{l}a \\
b\end{array}$ & $\begin{array}{l}\text { NOT } \\
\text { TOO MUCH }\end{array}$ & $\begin{array}{l}\text { See 2.2.a } \\
\text { See 5.3.c }\end{array}$ & $\begin{array}{l}\text { See 2.2.a } \\
\text { See 5.3.c }\end{array}$ & $\begin{array}{l}\text { See 2.2.a } \\
\text { See 5.3.c }\end{array}$ & $\begin{array}{l}\text { See 2.2.a } \\
\text { See 5.3.c }\end{array}$ \\
\hline 1.2 .4 & $\mathbf{C}$ & $\begin{array}{l}\text { Maintain water seal in } \\
\text { D-102 to prevent gas } \\
\text { entering sewer. }\end{array}$ & $\mathbf{a}$ & NOT & Loss of water seal. & See 5.3.c & See 5.3.c & See 5.3.c \\
\hline 2.0 & I & Compress gas to $40 \mathrm{bar}$ & & & & & & \\
\hline 2.1 & $\mathbf{M}$ & $\begin{array}{l}\text { Compress gas in a } \\
\text { reciprocating com- } \\
\text { pressor }\end{array}$ & a & $\begin{array}{l}\text { NOT } \\
\text { TOO MUCH }\end{array}$ & $\begin{array}{l}\text { Low pressure at exit. } \\
\text { High pressure at exit. }\end{array}$ & $\begin{array}{l}\text { Possible damage to } \\
\text { down-stream plant. }\end{array}$ & $\begin{array}{l}\text { Pressure relief valve } \\
\text { fitted. }\end{array}$ & $\begin{array}{l}\text { Process engincering to } \\
\text { advise. } \\
\text { Consider adding high- } \\
\text { pressure to comp. trip. }\end{array}$ \\
\hline 2.2 & $\mathbf{C}$ & $\begin{array}{l}\text { Gas to be compressed } \\
\text { must be dry }\end{array}$ & $\mathbf{a}$ & NOT & $\begin{array}{l}\text { Wet gas enters } \\
\text { compressor. }\end{array}$ & $\begin{array}{l}\text { Severe damage to } \\
\text { compressor, leading to } \\
\text { possible release of } \\
\text { flammables. }\end{array}$ & & \\
\hline
\end{tabular}


ลิ

\begin{tabular}{|c|c|c|c|c|c|c|c|c|}
\hline \multicolumn{3}{|c|}{ FUNCTION } & \multicolumn{6}{|c|}{ HAZARD IDENTIFICATION } \\
\hline Ref & $\mathbf{T}$ & Description & $\mathbf{k}$ & Keyword & Main variance & Consequences & Mitigation & Notes \\
\hline 3.0 & 1 & Support operation & & & & & & \\
\hline 3.1 & $\mathbf{M}$ & $\begin{array}{l}\text { Maintain process } \\
\text { equipment }\end{array}$ & & See $3.1 .0-3.1 .8$ & See 3.1.0-3.1.8 & See $3.1,0-3.1 .8$ & See $3.1,0-3.1 .8$ & See $3,1,0-3,1.8$ \\
\hline 3.2 & $\mathbf{M}$ & Disposal of waste & $\begin{array}{l}\text { a } \\
\text { b }\end{array}$ & $\begin{array}{l}\text { NOT } \\
\text { NOT } \\
\text { NOT } \\
\text { NOT }\end{array}$ & $\begin{array}{l}\text { Fail safely to dispose of } \\
\text { waste gasses. } \\
\text { Fail to safely dispose of } \\
\text { effluent from D-102 } \\
\text { Fail safely to dispose of } \\
\text { spent catalyst from R- } \\
101 \\
\text { Fail safely to dispose of } \\
\text { lubricating oil from } \\
\text { compressor C-102. }\end{array}$ & $\begin{array}{l}\text { Possible fire or } \\
\text { explosion. } \\
\text { Possible pollution and } \\
\text { fire or explosion from } \\
\text { dissolved gasses. }\end{array}$ & & $\begin{array}{l}\text { Insufficient information } \\
\text { available on catalyst } \\
\text { and its characteristics. }\end{array}$ \\
\hline 3.3 & $\mathbf{M}$ & Control the process & & & & & & \\
\hline 3.4 & $\mathbf{M}$ & Manage emergencies & & & & & & \\
\hline 3.5 & $\mathbf{M}$ & Catalyst loading & $\begin{array}{l}\text { a } \\
\text { b }\end{array}$ & $\begin{array}{l}\text { TOXICITY } \\
\text { CONTAMI- } \\
\text { NATION } \\
\text { DROP }\end{array}$ & $\begin{array}{l}\text { Catalyst may present a } \\
\text { toxic hazard. } \\
\text { Contaminated catalyst } \\
\text { may cause adverse or } \\
\text { nunaway reactions. } \\
\text { Catalyst loading may } \\
\text { involve manipulating } \\
\text { heavy loads at elevated } \\
\text { sites and in difficult } \\
\text { conditions. }\end{array}$ & $\begin{array}{l}\text { Possible harm to } \\
\text { personnel. } \\
\text { Possible injury to } \\
\text { personnel. }\end{array}$ & & $\begin{array}{l}\text { Need to review catalyst } \\
\text { loading/unloading } \\
\text { procedures. }\end{array}$ \\
\hline
\end{tabular}




\begin{tabular}{|c|c|c|c|c|c|c|c|c|}
\hline \multicolumn{3}{|c|}{ FUNCTION } & \multicolumn{6}{|c|}{ HAZARD IDENTIFICATION } \\
\hline Ref & $\mathbf{T}$ & Description & $k$ & Keyword & Main variance & Consequences & Mitigation & Notes \\
\hline 3.6 & $\mathbf{M}$ & Security & & & & & & \\
\hline 3.7 & $\mathbf{M}$ & $\begin{array}{l}\text { Star-up the system } \\
\text { safely. }\end{array}$ & & & & & & \\
\hline 3.1 .0 & I & $\begin{array}{l}\text { Maintain process } \\
\text { equipment }\end{array}$ & $\begin{array}{l}a \\
b\end{array}$ & $\begin{array}{l}\text { FLAMMABLES } \\
\text { TEMPERATURE } \\
\text { PRESSURE }\end{array}$ & $\begin{array}{l}\text { Release of nammables } \\
\text { during maintenance. } \\
\text { Personnel fail to observe } \\
\text { procedures for working } \\
\text { on high temp. } \\
\text { equipment. } \\
\text { Personnel fail to observe } \\
\text { procedures for working } \\
\text { on high press. } \\
\text { equipment. }\end{array}$ & $\begin{array}{l}\text { Fire, explosion. } \\
\text { Burns to personnel. } \\
\text { Kinetic injuries to } \\
\text { personnel. }\end{array}$ & & $\begin{array}{l}\text { See also } 3.5 \text {, catalyst } \\
\text { loading. }\end{array}$ \\
\hline 3.1 .1 & $\mathbf{M}$ & Maintain R-101 & & See 3.1.0 & & & & \\
\hline 3.1 .2 & $\mathbf{M}$ & $\begin{array}{l}\text { Maintain heal } \\
\text { exchanger E-101 }\end{array}$ & & See 3.1.0 & & & & \\
\hline 3.1 .3 & $\mathbf{M}$ & $\begin{array}{l}\text { Maintain heal } \\
\text { exchanger E-102 }\end{array}$ & & See 3.1.0 & & & & \\
\hline 3.1 .4 & $\mathbf{M}$ & $\begin{array}{l}\text { Maintain KO-pot D- } \\
102\end{array}$ & $\begin{array}{l}\mathbf{a} \\
\mathbf{b}\end{array}$ & $\begin{array}{l}\text { See } 3.1 .0 \\
\text { PROCEDURE } \\
\text { PROCEDURE }\end{array}$ & $\begin{array}{l}\text { Failure to observe } \\
\text { procedures leads to loss } \\
\text { of water seal in D-102. } \\
\text { Failure to observe } \\
\text { procedure leads to water } \\
\text { carry-over from D-102. }\end{array}$ & $\begin{array}{l}\text { Release of flammables, } \\
\text { fire, explosion. } \\
\text { Damage to downstream } \\
\text { compressor. }\end{array}$ & & \\
\hline
\end{tabular}




\begin{tabular}{|c|c|c|c|c|c|c|c|c|}
\hline \multicolumn{3}{|c|}{ FUNCTION } & \multicolumn{6}{|c|}{ HAZARD IDENTIFICATION } \\
\hline Ref & $\mathbf{k}$ & Description & k & Keyword & Main variance & Consequences & Mitigation & Notex \\
\hline 3.1.5 & $\mathbf{M}$ & $\begin{array}{l}\text { Maintain compressor } \\
\text { C-102 }\end{array}$ & $\begin{array}{l}a \\
b\end{array}$ & $\begin{array}{l}\text { See 3.1.0 } \\
\text { PROCEDURES }\end{array}$ & $\begin{array}{l}\text { Failure to observe } \\
\text { procedures. }\end{array}$ & $\begin{array}{l}\text { Damage to compressor: } \\
\text { poss. damage to or loss } \\
\text { of feed to downstream } \\
\text { plant. Possible injury to } \\
\text { personnel from rotating } \\
\text { equipment, high } \\
\text { voltages, etc. }\end{array}$ & & \\
\hline 3.1 .6 & $\mathbf{M}$ & $\begin{array}{l}\text { Maintain instrumenta- } \\
\text { tion and control sys- } \\
\text { tems. }\end{array}$ & a & NOT & Failure to maintain. & $\begin{array}{l}\text { Loss of control leading } \\
\text { to release of flammables } \\
\text { or off-spec product. }\end{array}$ & & \\
\hline 3.1.7 & $\mathbf{M}$ & $\begin{array}{l}\text { Maintain methanator } \\
\text { trip system }\end{array}$ & b & $\begin{array}{l}\text { NOT } \\
\text { TEST } \\
\text { TEST }\end{array}$ & $\begin{array}{l}\text { Failure to maintain } \\
\text { methanator trip system } \\
\text { Fail to test trip system } \\
\text { at prescribed intervals. } \\
\text { Test trip system more } \\
\text { often than prescribed. }\end{array}$ & $\begin{array}{l}\text { Premature failure of trip } \\
\text { system. with either } \\
\text { spurious shutdown or } \\
\text { loss of protection. } \\
\text { Possibility of dormant } \\
\text { failures. } \\
\text { Increased exposure to } \\
\text { real trip during test. }\end{array}$ & & \\
\hline 3.1 .8 & $\mathbf{M}$ & $\begin{array}{l}\text { Maintain compressor } \\
\text { trip system }\end{array}$ & $\begin{array}{l}\text { b } \\
\text { c }\end{array}$ & $\begin{array}{l}\text { NOT } \\
\text { TEST } \\
\text { TEST }\end{array}$ & $\begin{array}{l}\text { Failure to maintain } \\
\text { compressor trip system } \\
\text { Fail to test trip system } \\
\text { at prescribed intervals. } \\
\text { Test trip system more } \\
\text { often than prescribed. }\end{array}$ & $\begin{array}{l}\text { Premature failure of trip } \\
\text { system, with either } \\
\text { spurious shutdown or } \\
\text { loss of protection. } \\
\text { Possibility of dormant } \\
\text { failures. } \\
\text { Increased exposure to } \\
\text { real trip during lest. }\end{array}$ & None. & \\
\hline
\end{tabular}




\begin{tabular}{|c|c|c|c|c|c|c|c|c|}
\hline \multicolumn{3}{|c|}{ PUNCTION } & \multicolumn{6}{|c|}{ HAZARD IDENTIFICATION } \\
\hline Ret & $\mathbf{T}$ & Description & k & Keyword & Main varlance & Conesquences & Mitization & Notes \\
\hline 5.0 & 1 & $\begin{array}{l}\text { Protect environment } \\
\text { from plant. }\end{array}$ & & & & 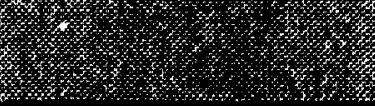 & (1: & 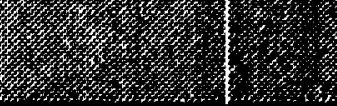 \\
\hline 5.1 & $\mathbf{M}$ & Contain process fluids & a & NOT & $\begin{array}{l}\text { Flammable gas released } \\
\text { to atmosphese. }\end{array}$ & $\begin{array}{l}\text { Possible fire and } \\
\text { explosion. }\end{array}$ & $\begin{array}{l}\text { Mainctain stundurds of } \\
\text { construction by regular } \\
\text { inspections and } \\
\text { preventive } \\
\text { maintenance. Consider } \\
\text { gas detectors and water } \\
\text { sprays at critical } \\
\text { locations. }\end{array}$ & \\
\hline 5.2 & $\mathbf{M}$ & $\begin{array}{l}\text { Avoid release of proc- } \\
\text { ess malerials. }\end{array}$ & $\mathbf{a}$ & NOT & $\begin{array}{l}\text { Release flammable } \\
\text { malerials to flare. where } \\
\text { they are bumed. }\end{array}$ & $\begin{array}{l}\text { Unnecessary loss of } \\
\text { energy. bright lights at } \\
\text { night. elc. }\end{array}$ & $\begin{array}{l}\text { Consider use of off. } \\
\text { spec gas as fuel. }\end{array}$ & \\
\hline 5.3 & $\mathbf{M}$ & $\begin{array}{l}\text { Ensure safe efnuent } \\
\text { disposal }\end{array}$ & c & $\begin{array}{l}\text { NOT } \\
\text { TOXICITY } \\
\text { FLAMMABLES }\end{array}$ & $\begin{array}{l}\text { Fail to ensure sare } \\
\text { disposal of effuent } \\
\text { which may be toxic or } \\
\text { nammable. } \\
\text { Fail to ensure sare } \\
\text { disposal of liquid } \\
\text { draining trom D-102 } \\
\text { which will contain } \\
\text { dissolved hydrogen and } \\
\text { methane. }\end{array}$ & $\begin{array}{l}\text { Hydrogen und/or } \\
\text { methane will be } \\
\text { liberated in the sewers, } \\
\text { where il may be } \\
\text { transporied considerable } \\
\text { distances before } \\
\text { reaching a source of } \\
\text { ignition. }\end{array}$ & $\begin{array}{l}\text { Install gns delectors } \\
\text { and forced ventilation } \\
\text { system with safe } \\
\text { dispossal of liberated } \\
\text { suases. }\end{array}$ & $\begin{array}{l}\text { Need lo determine } \\
\text { whether spent cacalyst } \\
\text { of malerials carried } \\
\text { forward from upsiream } \\
\text { plant ure toxic. } \\
\text { Consider a second } \\
\text { vessel at near } \\
\text { almospheric pressure. } \\
\text { where gusses may be } \\
\text { surely libernied and } \\
\text { disposed of before } \\
\text { effuent is iransferred } \\
\text { to the sewer. }\end{array}$ \\
\hline
\end{tabular}




\begin{tabular}{|c|c|c|c|c|c|c|c|c|}
\hline \multicolumn{3}{|c|}{ FUNCTION } & \multicolumn{6}{|c|}{ HAZARD IDENTIFICATION } \\
\hline Ref & $\mathbf{T}$ & Description & k & Keyword & Main varlance & Conusquances & Milization & Nore: \\
\hline 5.4 & $\mathbf{M}$ & $\begin{array}{l}\text { Avoid acoustic emis- } \\
\text { sions. }\end{array}$ & a & NOT & $\begin{array}{l}\text { High noise levels gene- } \\
\text { raled by compressors } \\
\text { and nures. }\end{array}$ & $\begin{array}{l}\text { Disturbance to local } \\
\text { pupulalion, lewding lo } \\
\text { adverse publicity and } \\
\text { general hostillity to plant } \\
\text { operalions. } \\
\text { Pussible lons-lerm } \\
\text { hearing damage to plant } \\
\text { penonnel. }\end{array}$ & $\begin{array}{l}\text { Perwonnel wre provided } \\
\text { with proxeclive } \\
\text { devices. }\end{array}$ & $\begin{array}{l}\text { Need io examine welual } \\
\text { noise levels or } \\
\text { expecied levels from } \\
\text { prior experience. }\end{array}$ \\
\hline 6.0 & 1 & $\begin{array}{l}\text { Protect plani from en. } \\
\text { vironment }\end{array}$ & & & & & & 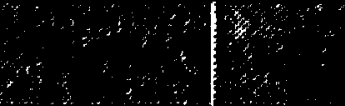 \\
\hline 6.1 & $\mathbf{M}$ & $\begin{array}{l}\text { Protect against inci- } \\
\text { dents in adjacent plant. }\end{array}$ & a & See 6.2.b.c.d & See 6.2.b.c.d & Sec 6.2.b.c.d & See 6.2.b.c.d & See 6.2.b.c.d \\
\hline
\end{tabular}




\begin{tabular}{|c|c|c|c|c|c|c|c|c|}
\hline \multicolumn{3}{|c|}{ FUNCTION } & \multicolumn{6}{|c|}{ HAZARD IDENTIFICATION } \\
\hline Ref & $\mathbf{T}$ & Deacription & $k$ & Konvword & Main varinace & Consogunoncen & Mirigation & Nates \\
\hline 6.2 & $M$ & $\begin{array}{l}\text { Prokeel against mun- } \\
\text { made disasters. }\end{array}$ & a & $\begin{array}{l}\text { ACCIDENTAL } \\
\text { IMPACT. } \\
\text { EXTERNAL } \\
\text { ENERGETIC } \\
\text { EVENT } \\
\\
\text { EXTERNAL } \\
\text { TOXIC EVENT } \\
\\
\text { EXTERNAL } \\
\text { CONTAMI. } \\
\text { NATION }\end{array}$ & $\begin{array}{l}\text { Vohicle innpact with } \\
\text { plant. } \\
\text { Energetic cvent in } \\
\text { adjucent plant. } \\
\text { Toxic release trom } \\
\text { ixdjacent plant. } \\
\text { Releuse of } \\
\text { contuminating material } \\
\text { from adjacent plant. }\end{array}$ & 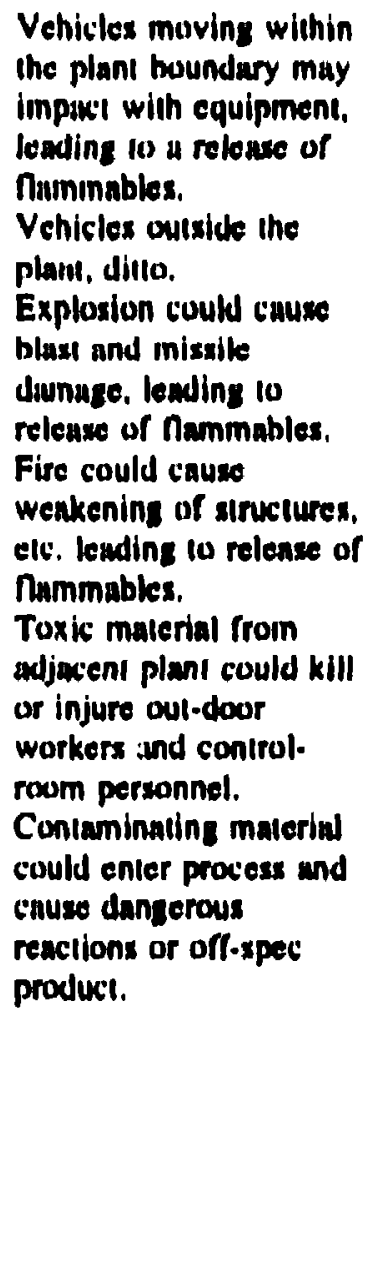 & 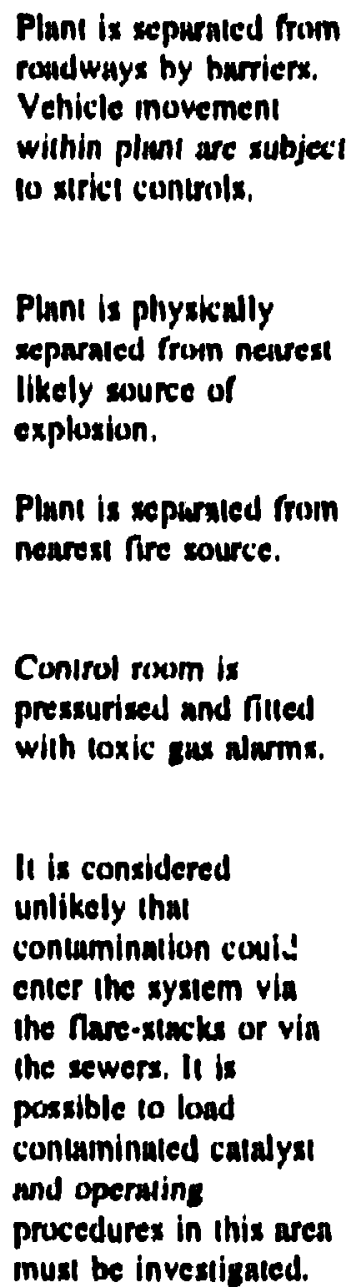 & 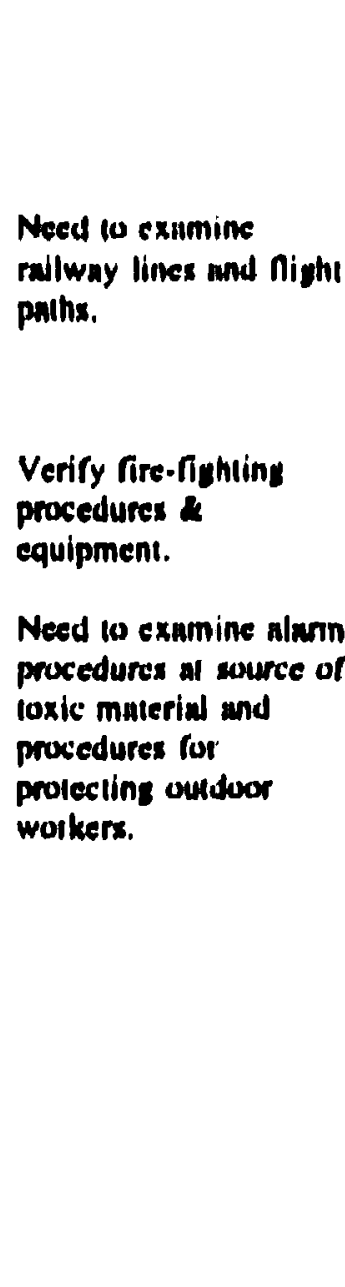 \\
\hline
\end{tabular}




\begin{tabular}{|c|c|c|c|c|c|c|c|c|}
\hline \multicolumn{3}{|c|}{ FUNCTION } & \multicolumn{6}{|c|}{ HAZARD IDENTIFICATION } \\
\hline Ref & $\mathbf{T}$ & Description & $\mathbf{k}$ & Keyword & Main variance & Consequences & Mitigation & Notes \\
\hline 6.3 & $\mathbf{M}$ & $\begin{array}{l}\text { Protect against natural } \\
\text { disasters. }\end{array}$ & $\mathbf{a}$ & $\begin{array}{l}\text { EXTREME } \\
\text { WEATHER } \\
\text { EXTREME } \\
\text { WEATHER } \\
\text { EXTREME } \\
\text { WEATHER } \\
\\
\text { EXTREME } \\
\text { WEATHER } \\
\text { EARTHQUAKE }\end{array}$ & $\begin{array}{l}\text { Lightning strikes to } \\
\text { plant. } \\
\text { Wind damage. } \\
\text { Extreme cold. } \\
\text { Extreme cold. } \\
\text { Structural damage. }\end{array}$ & $\begin{array}{l}\text { Could cause structural } \\
\text { damage, leading to } \\
\text { release and ignition of } \\
\text { gas. } \\
\text { High winds may cause } \\
\text { collapse of especially } \\
\text { tall structures. } \\
\text { Freezing of entrapped } \\
\text { water and other fluids. } \\
\text { leading to fracture of } \\
\text { pipes etc. on melting } \\
\text { and subsequent release } \\
\text { of flammables. } \\
\text { Possible britte fracture } \\
\text { of metals, leading to } \\
\text { release of flammables. } \\
\text { Loss of plant integrity, } \\
\text { leading to release of } \\
\text { flammables. }\end{array}$ & $\begin{array}{l}\text { Plant location makes } \\
\text { seismic events } \\
\text { extremely unlikely. }\end{array}$ & $\begin{array}{l}\text { Extremes of solar } \\
\text { radiation, flooding. or } \\
\text { tidal waves are } \\
\text { assumed unlikely } \\
\text { because of the plant's } \\
\text { location. }\end{array}$ \\
\hline
\end{tabular}




\begin{tabular}{|c|c|c|c|c|c|c|c|c|}
\hline \multicolumn{3}{|c|}{ FUNCTION } & \multicolumn{6}{|c|}{ HAZARD IDENTIFICATION } \\
\hline Ref & $\mathbf{T}$ & Description & $\mathbf{k}$ & Keyword & Main variance & Consequences & Mitigation & Notes \\
\hline 6.4 & $\mathbf{M}$ & $\begin{array}{l}\text { Protect against unau- } \\
\text { thorised access to } \\
\text { plant. }\end{array}$ & $\mathbf{b}$ & $\begin{array}{l}\text { NOT } \\
\text { EMERGENCY } \\
\text { SABOTAGE } \\
\text { THEFT }\end{array}$ & $\begin{array}{l}\text { Unauthorised persons } \\
\text { gain access to plant. } \\
\text { as above } \\
\text { as above } \\
\text { as above }\end{array}$ & $\begin{array}{l}\text { Persons pose a risk to } \\
\text { the plant through } \\
\text { accidental or deliberate } \\
\text { interference and are } \\
\text { themselves at risk } \\
\text { Well-intentioned } \\
\text { intruders, eg press and } \\
\text { families of staff, may } \\
\text { interfere with emergency } \\
\text { operations. } \\
\text { Plant represents a } \\
\text { dangerous reaction with } \\
\text { a hazardous substance } \\
\text { and sabotage would be } \\
\text { simple and catastrophic. } \\
\text { Catalyst is valuable but } \\
\text { impossible to steal while } \\
\text { operating! However, } \\
\text { theft of catalyst is } \\
\text { possible during } \\
\text { (un)loading operations } \\
\text { or when catalyst is } \\
\text { stored at site. }\end{array}$ & & \\
\hline 7.0 & 1 & $\begin{array}{l}\text { Inlet } \mathrm{CO} / \mathrm{CO}_{2} \text { content } \\
\leq 10 \%\end{array}$ & $\mathbf{a}$ & NOT & $\mathrm{CO} / \mathrm{CO}_{2}$ content $>10 \%$ & $\begin{array}{l}\text { Runaway reaction in } R- \\
101 \text {, leading to over- } \\
\text { temperature, failure of } \\
R-101 \text { and release of } \\
\text { flammable gas. }\end{array}$ & $\begin{array}{l}\mathrm{CO} / \mathrm{CO}_{2} \text { content is } \\
\text { monitored and alarmed } \\
\text { by QA. } \mathrm{R}-101 \text { is } \\
\text { protected by a trip } \\
\text { system. }\end{array}$ & $\begin{array}{l}\text { Consider that } Q A \\
\text { should be integrated } \\
\text { with the trip system. }\end{array}$ \\
\hline
\end{tabular}




\begin{tabular}{|c|c|c|c|c|c|c|c|c|}
\hline \multicolumn{3}{|c|}{ FUNCTION } & \multicolumn{6}{|c|}{ HAZARD IDENTIFICATION } \\
\hline Ref & $\mathbf{T}$ & Description & k & Keyword & Main variance & Consequences & Mitigation & Notes \\
\hline 8.0 & $\mathbf{I}$ & $\begin{array}{l}\text { Outlet } \mathrm{CO} / \mathrm{CO}_{2} \text { content } \\
\leq 10 \mathrm{ppm}\end{array}$ & a & NOT & $\begin{array}{l}\mathrm{CO} / \mathrm{CO}_{2} \text { content } \geq 10 \\
\mathrm{ppm}\end{array}$ & $\begin{array}{l}\text { Serious effects possible } \\
\text { ito downstream process. }\end{array}$ & None. & $\begin{array}{l}\text { Recommend trip } \\
\text { system based on outlet } \\
\text { conc. Which is worse: } \\
\text { interrupt gas flow or } \\
\text { supply off-spec gas? } \\
\text { Process enginering to } \\
\text { advise. }\end{array}$ \\
\hline 9.0 & $\mathbf{I}$ & Inlet pressure $20 \mathrm{bar}$ & & & & & & $\begin{array}{l}\text { Process engineering to } \\
\text { advise. }\end{array}$ \\
\hline 10.0 & $\mathbf{I}$ & Outlet pressure 40 bar & & & & & & $\begin{array}{l}\text { Process engineering to } \\
\text { advise. }\end{array}$ \\
\hline 11.0 & $\mathbf{I}$ & Inlet temperature tbd & & & & & & $\begin{array}{l}\text { Process engineering to } \\
\text { advise. }\end{array}$ \\
\hline 12.0 & $\mathbf{I}$ & Outlet temperature tbd & & & & & & $\begin{array}{l}\text { Process engineering to } \\
\text { advise. }\end{array}$ \\
\hline
\end{tabular}


Title and authors(s)

Hazard Identification Based on Plant Functional Modelling

Birgitte Rasmussen, Cris Whetton

\begin{tabular}{|c|c|c|c|}
\hline \multicolumn{3}{|l|}{ ISBN } & ISSN \\
\hline \multicolumn{3}{|c|}{$87-550-1933-1$} & $0106-2840$ \\
\hline \multicolumn{3}{|c|}{ Dept. or group } & Date \\
\hline \multicolumn{3}{|c|}{ Systems Analysis Department } & October 1993 \\
\hline \multicolumn{3}{|c|}{ Groups own reg-number(s) } & Project/contract no.(s) \\
\hline \multicolumn{3}{|c|}{ RAG-2714-00 } & STEP-CT90-0085 \\
\hline Pages & Tables & Ilustrations & References \\
\hline 71 & 4 & 10 & 7 \\
\hline
\end{tabular}

Abstract (Max. 2000 characters)

A major objective of the present work is to provide means for representing a process plant as a socio-technical system, so as to allow hazard identification at a high level. The method includes technical, human and organisational aspects and is intended to be used for plant level hazard identification so as to identify critical areas and the need for further analysis using existing methods. The first part of the method is the preparation of a plant functional model where a set of plant functions link together hardware, software, operations, work organisation and other safety related aspects of the plant. The basic principle of the functional modelling is that any aspect of the plant can be represented by an object (in the sense that this term is used in computer science) based upon an Intent (or goal); associated with each Intent are Methods, by which the Intent is realized, and Constraints, which limit the Intent. The Methods and Constraints can themselves be treated as objects and decomposed into lower-level Intents (hence the procedure is known as functional decomposition) so giving rise to a hierarchical, object-oriented structure. The plant level hazard inentification is carried out on the plant functional model using the Concept Hazard Aralysis method. In this, the users will be supported by checklists and keywords and the analysis is structured by pre-defined worksheets. The preparation of the plant functional model and the performance of the hazard identification can be carried out manually or with computer support.

Descriptors INIS/EDB

CHEMICAL PLANTS; FUNCTIONAL MODELS; HAZARDS; SAFETY ANALYSIS; SYSTEMS ANALYSIS

Available on request from Riso Librery.Riso National Laboratory.(Riso Bibliolek,Forskningscenter Riso), P.0. Box 49 ,

DK-4000 Roskilde, Denmark.

Telephone +45 46774677 , exi. 4004/4005

Telex 43 116. Telefax +4542360609 . 


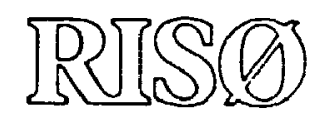

\section{OBJECTIVE}

The objective of Ris National

Laboratory is to further techno-

logical development in three main

areas: energy, environment and

materials.

\section{USERS}

Risø's scientific results are widely applied in industry, agriculture and public services. Ris $₫$ contributes its share of new knowledge to the global research community.

\section{RESEARCH PROFILE}

Risø emphasises long-term and strategic research providing a solid scientific foundation for the technological development of society.

Riso-R-712(EN)

ISBN 87-550-1933-1

ISSN 0106-2840

Available on request from:

Riso Library

Riso National Laboratory

P.O. Box 49, DK-4000 Roskilde, Denmark Phone +45 46774677 , ext. 4004/4005

Telex 43116, Telefax 46755627

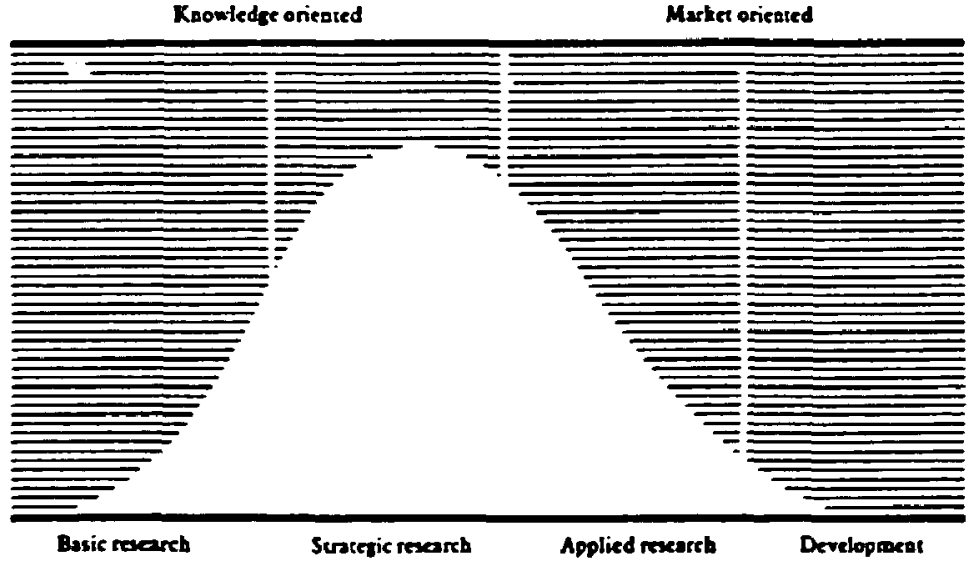

PRIORITY AREAS

- Combustion and gasification

- Wind energy

- Energy materials

- Energy and environmental planning

- Assessment of environmental loads

- Reduction of environmental loads

- Safety and reliability of technical systems

- Nuclear safety

- Atomic structure and properties of materials

- Advanced materials and materials technologies

- Optics and fluid dynamics 